ORIGINALMENTE PUBLICADO EM: POSNER, ERIC A. SYMBOLS, SIGNALS, AND SOCIAL NORMS IN POLITICS AND THE LAW. THE JOURNAL OF LEGAL STUDIES, VOL. 27, NO. 2, SOCIAL NORMS, SOCIAL MEANING, AND THE ECONOMIC ANALYSIS OF LAW (JUN., 1998), PP. 765-798.

\title{
SÍMBOLOS, SINAIS E NORMAS SOCIAIS NA POLÍTICA E NO DIREITO
}

\author{
Eric A. Posner
}

SYMBOLS, SIGNALS, AND SOCIAL NORMS IN POLITCS

tRadução José Rodrigo Rodriguez Revisão da tRadução Maria Carolina Foss notas Bruno Meyerhof Salama, Maria Carolina Foss e José Rodrigo Rodriguez

\section{RESUMO}

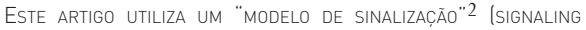
MODEL) PARA EXPLICAR O PAPEL DOS SÍMBOLOS NO COMPORTAMENTO E NAS CRENÇAS, ESPECIALMENTE QUANTO À MANIPULAÇÃO DOS SÍMBOLOS POR MEIO DO SISTEMA JURÍDICO. ARGUMENTA-SE QUE CERTAS AÇÕES TORNAM-SE SIMBÓLICAS PORQUE TÊM A "ESTRUTURA DE CUSTO" (COST STRUCTURE) ADEQUADA E PORQUE SÃO, POR RAZÕES HISTÓRICAS OU PSICOLÓGICAS, FOCAIS. ${ }^{3}$ A ESTRUTURA DE CUSTO PERMITE QUE AS PESSOAS OBTENHAM VANTAGENS AO REVELAR INFORMAÇÕES SOBRE ELAS EM UMA SITUAÇÃO DE "EQUILÍBRIO DIFERENCIADOR" 4 (SEPARATING EQUILIBRIA). A CARACTERÍSTICA FOCAL DA AÇÃO REMOVE AMBIGÜIDADES NA INTERPRETAÇÃO DOS MOTIVOS PELOS QUAIS ALGUÉM SE ENGAJA NELA. TEORICAMENTE, O GOVERNO PODE UTILIZAR INSTRUMENTOS LEGAIS PADRONIZADOS (QUE AFETEM, PRINCIPALMENTE, O CUSTO DO SINAL) PARA MUDAR O EQUILÍBRIO ${ }^{5}$ DE COMPORTAMENTOS E CRENÇAS. USAR O DIREITO DESSA MANEIRA PODE PRODUZIR EFEITOS IMPREVISÍVEIS EM RAZÃO DOS MÚLTIPLOS EQUILÍBRIOS EXISTENTES E DAS DIVERSAS REAÇÕES POSSÍVEIS DO COMPORTAMENTO DOS INDIVÍDUOS EM RELAÇÃO AOS PARÂMETROS LEGAIS. NO ENTANTO, EFEITOS IMPREVISÍVEIS OCORREM, NA MAIOR PARTE DAS VEZES, PORQUE O ATO DE FAZER LOBBY E OUTROS ATOS QUE INFLUENCIAM NA CRIAÇÃO DAS LEIS PODEM SE TORNAR, ELES MESMOS, SINAIS. DESSA FORMA, O DIREITO SERÁ APENAS UM RESULTADO DO EQUILÍBRIO. A ANÁLISE É UTILIZADA PARA DISCUTIR O DESRESPEITO À BANDEIRA, À CENSURA, AO VOTO E ÀS LEIS CONTRA A DISCRIMINAÇÄO.

PALAVRAS-CHAVE

Símbolos, Sinais e Normas Sociais na Política e no Direito

\section{ABSTRACT}

THIS ARTICLE USES A SIGNALING MODEL TO EXPLAIN THE ROLE OF SYMBOLS IN PEOPLE'S BEHAVIOR AND BELIEFS, WITH SPECIAL ATTENTION TO LEGAL MANIPULATION OF SYMBOLS. IT IS ARGUED THAT CERTAIN ACTIONS BECOME SYMBOLIC BECAUSE THEY HAVE THE PROPER COST

STRUCTURE AND BECAUSE THEY ARE, FOR HISTORICAL OR PSYCHOLOGICAL REASONS, FOCAL. THE GOVERNMENT CAN IN THEORY USE STANDARD LEGAL INSTRUMENTS (WHICH MAINLY AFFECT THE COST OF THE SIGNAL) TO CHANGE EQUILIBRIUM BEHAVIOR AND BELIEF. THE USE OF THE LAW IN THIS WAY IS LIKELY TO HAVE UNPREDICTABLE EFFECTS BECAUSE OF MULTIPLE EQUILIBRIA AND OF THE SENSITIVITY OF BEHAVIOR TO PARAMETERS, BUT IT OCCURS FREQUENTLY BECAUSE LOBBYING AND OTHER ACTIONS THAT INFLUENCE LAWMAKING CAN BECOME SIGNALS THEMSELVES, AND THE LAW IS SIMPLY AN EQUILIBRIUM OUTCOME. THE ANALYSIS IS USED TO DISCUSS FLAG DESECRATION, CENSORSHIP, VOTING, AND ANTIDISCRIMINATION LAWS.

\section{KEYWORDS}

SOVEREIGNTY, INTERNATIONAL TREATIES, TAX LAW, DOUBLE Symbols, Signals, And Social Norms in Politcs and LaW 


\section{APresentaÇÃo da TRADUÇÃo}

Este texto de Eric Posner, Professor de Direito da Universidade de Chicago, apesar de ter sido publicado recentemente, é uma referência fundamental para o campo de estudos denominado Law \& Economics. Nele, o autor expande o alcance da metodologia deste campo para o estudo das normas sociais, mais especificamente, para o processo de interação simbólica entre os indivíduos. A leitura dos símbolos a partir deste modelo teórico abriu novos horizontes para a pesquisa, aprofundados pelo próprio autor no livro Law and Social Norms (Harvard University Press, 2000).

As explicações e hipóteses presentes no texto dialogam com diversas ciências humanas, especialmente direito e sociologia. Neste texto, Eric Posner desenvolve conceitos que buscam compreender a relação entre normas sociais e normas jurídicas, problema altamente complexo, estudado pela sociologia do direito sob a rubrica "juridificação". Trata-se de pensar a necessidade e a adequação de criar normas jurídicas para regular os vários ambientes sociais. Neles, já existem normas sociais que disciplinam o comportamento dos indivíduos, que interagem com as normas jurídicas e que são afetadas por elas. Ao pensar a relação entre normas sociais e normas jurídicas sob o ponto de vista da economia, Eric Posner é inovador, pois constitui um novo ponto de vista, a partir do qual pode-se estudar e discutir o problema.

Esta tradução é acompanhada de notas explicativas que visam facilitar a compreensão dos termos econômicos por leitores não especialistas nesse campo de estudos.

\section{José Rodrigo Rodriguez}




\section{INTRODUÇ̃̃o}

Os símbolos dominam a política dos Estados Unidos da América e permeiam suas leis, mas são mal compreendidos. O militante solitário que queima a bandeira americana na entrada de um tribunal inicia uma tempestade política e, quando a fumaça finalmente se dissipa, revela um sistema "jurídico" em grande confusão: líderes políticos condenando o perpetrador nos termos mais duros, promotores se esforçando para levá-lo aos tribunais, legisladores lutando para propor projetos de lei que tornem ilícito o desrespeito à bandeira; especialistas manipulando argumentos diante da possibilidade de emendar a constituição. De qualquer ponto de vista, esse é um tumulto extraordinário. De fato, a queima da bandeira não causa dano a ninguém. Em um país em que a visão política dominante sustenta que o principal objetivo do Estado é prevenir comportamentos danosos, a atenção dispensada à queima da bandeira - uma ação que não coage ou causa dano a ninguém - pode ser considerada apenas motivo de embaraço. É verdade que pessoas ficam ofendidas com o desrespeito de um símbolo, mas por que a bandeira dos Estados Unidos da América é um símbolo? E por que símbolos importam?

Que eles importam está acima de qualquer dúvida. Uma breve pesquisa revela a existência de uma multiplicidade de conflitos sobre símbolos, tanto nesse país quanto no exterior. Exemplos dos Estados Unidos da América incluem colocar gravuras com a representação do nascimento de Jesus e outros símbolos religiosos em prédios públicos, a exibição da bandeira confederada, que representa um símbolo dos campos de batalha, em certas universidades do Sul (SACK, 1997), a recusa de certos cidadãos em admitir os seus números da seguridade social e estampar slogans patrióticos nas placas de seus veículos, marchas de nazistas e dos membros da Klu Klux Klan, o "discurso do ódio" (hate speech ${ }^{6}$ ) nos campi universitários e as desculpas presidenciais às vítimas de políticas cruéis. No exterior, os exemplos incluem conflitos sobre o respeito em virtude da instituição do marco alemão como unidade monetária substituta ao "Reichsmark", ao canguru e ao Imperador do Japão (NASH, 1995; . SHENON, 1995; KRISTOF, 1995). A primeira reação dos cidadãos à queda dos regimes comunistas na Europa do Leste não foi a privatização da indústria ou a reforma de polícia secreta, mas a destruição das estátuas, ${ }^{7}$ a mudança do nome das ruas e a adoção de novos desenhos para as bandeiras nacionais.

Muitos desses exemplos parecem triviais, mas não se pode duvidar da influência dos símbolos em políticas e mudanças jurídicas substantivas. Comete suicídio um político que defenda a modificação "incorreta" (na visão de seus correligionários) da lei sobre o aborto ou tenha posições "incorretas" sobre a ação afirmativa (affirmative action), a Seguridade Social, o controle de armas e outros problemas políticos de grande repercussão. Em linhas gerais, pouco importa o quão trivial seja a modificação proposta. Quando os eleitores interpretam o apoio de um certo político a um programa como 
símbolo de seu compromisso com os valores e interesses desses mesmos eleitores, concessões políticas tornam-se difíceis, até mesmo impossíveis.

O que conta para o destaque conferido ao desrespeito à bandeira em detrimento de outras questões de puro simbolismo? Uma teoria afirma que a violação de símbolos causa "dano psíquico", outra argumenta que ela entra em conflito com as "normas sociais", mas essas teorias não explicam por que certos comportamentos têm ressonância simbólica tal, capaz de causar dano psíquico ou violar normas sociais, e outros comportamentos, não. A reivindicação de um direito de se ver livre de qualquer dano psíquico lançaria dúvidas, sobretudo, sobre todos os direitos liberais clássicos - liberdade de expressão, religião, privacidade e consciência. Para fundamentar uma ordem jurídica que proteja as pessoas de alguns danos psíquicos e não de outros, é preciso explicar como esses danos se produzem.

Este artigo usa um modelo de sinalização para explicar por que os símbolos importam. Símbolos importam porque a atitude manifesta de uma pessoa em relação aos símbolos diz aos outros algo sobre seu caráter. As pessoas confiam muito nessa informação para decidir realizar ou não comportamentos cooperativos em todos os domínios de suas vidas. De fato, porque os símbolos importam tanto, o esforço para mostrar respeito a eles faz surgir normas sociais. Quando os símbolos mudam, alguns obtêm vantagens ao formar relações cooperativas e outros perdem as vantagens que tinham. ${ }^{8}$ Como as mudanças simbólicas resultam em perdas materiais para algumas pessoas, elas resistem às tentativas, seja do governo ou de outras pessoas, de desafiar um determinado sistema simbólico. Além disso, como o comportamento cooperativo pode ser instável e, portanto, muito sensível aos símbolos, há um grande incentivo para que o governo regule os símbolos. De outro lado, há também um grande perigo envolvido nisso.

\section{AnÁlise}

\section{I Jogos CoOperativos 9}

$\mathrm{Na}$ vida cotidiana, estamos constantemente envolvidos em comportamentos simbólicos. Apertamos as mãos, aplaudimos nos teatros, saudamos a bandeira, usamos roupas da moda, trocamos alianças de casamento, nos curvamos, damos presentes, observamos protocolos diplomáticos e tratamos os superiores com deferência. Em todos esses casos, o comportamento simbólico visa fazer com que o receptor acredite que o emissor tem certas características, as quais não podem ser observadas diretamente pelo receptor. Quando o comportamento simbólico não visa, como nos casos listados acima, a objetivos obviamente privados, interesses "substantivos", todos compreendem sua natureza simbólica. Não se aplaude uma apresentação porque o ato de juntar as mãos seja agradável, mas porque o aplauso sinaliza para aquele 
que se apresentou e para o restante do público que o show agradou. Muitos comportamentos, no entanto, têm objetivos simbólicos e substantivos. Alguém pode discriminar o membro de uma minoria tanto porque não gosta dessa pessoa quanto para mostrar aos outros que não gosta dos membros daquela minoria. Alguém pode buscar educar-se tanto porque acredita que a educação vai melhorar suas habilidades quanto para mostrar aos seus empregadores que é esperto o suficiente para obter um título. Alguém pode participar de uma parada patriótica porque aprecia o espetáculo e porque quer mostrar aos seus vizinhos que tem sentimentos patrióticos.

Para captar essas idéias e suas implicações para o sistema jurídico, uso um modelo de sinalização. O modelo será referido como "jogo cooperativo". Cooperação refere-se a qualquer tipo de relação cooperativa que possa ser reduzida ao modelo do “dilema do prisioneiro", 10 inclusive assuntos relativos à família e relações sociais. No espaço de que disponho, poderei apenas esboçar o caminho que o argumento deve seguir. Uma análise mais detalhada deve esperar um trabalho mais longo.

Em jogos cooperativos, cidadãos de tipo superior ("cooperadores") preocupamse com ganhos futuros em relação aos ganhos presentes e, além disso, ganham mais em ações conjuntas do que em ações solitárias. De outro lado, cidadãos de tipo inferior ("trapaceiros") preocupam-se mais com o presente e têm oportunidades para agir individualmente e obter ganhos. Ambos os tipos de cidadão trapaceariam na encenação isolada do dilema do prisioneiro, mas, em uma versão em que esse jogo se repetisse sem prazo para terminar e gerasse as recompensas (payoffs) apropriadas para a ação de cada um, os cooperadores nunca trapaceariam e os trapaceiros sempre trapaceariam no primeiro movimento. Isso se deve ao fato de que os cooperadores preocupam-se suficientemente com os ganhos futuros para querer que o jogo continue, enquanto os trapaceiros dão mais valor aos ganhos imediatos do que ao oscilante fluxo de ganhos futuros.

Artificialmente, imaginemos que os dois tipos de cidadão ("emissores") buscam cooperar com os membros de um outro grupo ("receptores”). Imaginemos também que os receptores não possam distinguir os emissores pelo tipo. Se os receptores cooperarem com qualquer um que se aproxime deles, às vezes vão ganhar e às vezes perder. Como os cooperadores não trapaceiam no primeiro movimento do jogo de cooperação, os receptores saberão identificá-los e os dois jogadores poderão, então, cooperar indefinidamente e obter ganhos mútuos. Os trapaceiros trapaceiam logo no primeiro movimento, assim, os receptores deixarão de cooperar nos próximos movimentos, mas já suportaram uma perda pontual. A depender da fração de trapaceiros em uma população dada e da diferença entre ganhos derivados da cooperação e da trapaça, emissores podem ter a propensão de cooperar com qualquer um. No entanto, se as perdas esperadas no futuro superarem os ganhos, os emissores se recusarão a cooperar com quem quer que seja. 
Para evitar a possibilidade de que os receptores não cooperem com eles, os cidadãos de tipo superior emitem sinais para os receptores que devem fornecer evidências com credibilidade suficiente para demonstrar que se está tratando com um cidadão daquele tipo, e não de outro. Um sinal é uma ação custosa (costly action) que, se bemsucedida, evidencia que tipo de cidadão o emissor é. Um sinal será capaz de distinguir um cooperador de um trapaceiro apenas se o primeiro for capaz de suportar os custos de utilizá-lo e o segundo, não. Exemplos de sinais discutidos na literatura incluem: dar presentes, fazer propaganda, consumir produtos de luxo ou da moda (CAMERER, 1988, p. S180-S214; KLEIN; LEFFLER, 1981, p. 615-641; PESENDORFER, 1995, p. 771-792; BAGWELL; BERNHEIM, 1996, p. 349-373). Aquele que se engaja nesse tipo de ação mostra aos outros que espera obter altos retornos da cooperação; do contrário, ele não arcaria com os custos para usar o sinal. Deve-se enfatizar que sinais podem ser ambíguos: a ação de dar um presente, por exemplo, pode refletir a generosidade e o altruísmo de uma pessoa, e não sua taxa de desconto (POSNER, 1997, p. 579-580). Ademais, deve-se enfatizar que sinais dotados da estrutura de custo errada, ou seja, sinais muito caros ou muito baratos, podem ser inadequados para distinguir cooperadores de trapaceiros, levando a um estado de equilíbrio em que todos emitem um sinal ou todos o abandonam. Cooperadores emitem sinais para explicitar seu tipo; se os sinais forem dotados da estrutura de custo errada, os trapaceiros vão copiá-los. Se os cooperadores forem bem-sucedidos na ação de distinguir a si mesmos dos trapaceiros, os receptores cooperarão com os cooperadores; do contrário, não (ou se as recompensas forem adequadas, receptores cooperarão, na mesma proporção, com cooperadores e trapaceiros).

Muitos sinais têm recebido pouca atenção da literatura, a despeito de sua grande importância. Alguém realiza ações custosas quando mostra respeito pela bandeira, cumpre seus deveres cívicos de votar e participar de júris populares e evita qualquer relacionamento com pessoas consideradas inimigas do Estado, mas que, de fato, são, no curto prazo, parceiros desejáveis e cooperadores. Uma ação pode servir como um sinal em três hipóteses: se os receptores a interpretarem como evidência de estarem diante de um cidadão de um certo tipo ${ }^{11}$ se essa ação for barata o suficiente para que os cooperadores possam recuperar seus custos com as recompensas advindas da cooperação e, ainda, se ela for custosa o suficiente para que os trapaceiros possam recuperar seus custos ao desistirem no primeiro movimento do jogo. O porquê de essas ações, e não outras igualmente custosas (como sentar num pilar por um mês), funcionarem como sinais será discutido adiante. Quando eu centrar minha atenção neste tipo de sinal em contraste com ações como dar presentes, fazer propaganda e outras do mesmo tipo, vou me referir ao jogo de cooperação como "jogo de patriotismo", a despeito de ambos serem formalmente idênticos.

Para dar ao leitor uma noção mais precisa da influência dos sinais sobre o comportamento, vou esboçar aqui seus pontos centrais com a utilização de um exemplo 
numérico simples (KLEIN; LEFFLER, 1981, p. 615-641; MILGROM; ROBERTS, 1986, p. 796-821). ${ }^{12}$ Para os fins deste exemplo, vou me referir de maneira estilizada, , nas ocasiões apropriadas, ao sinal "saudar a bandeira". Esse comportamento, que pode parecer muito barato para servir como um sinal, deve ser tomado como metonímia de comportamentos patrióticos como os mencionados acima e será colocado no contexto adequado nas próximas seções deste artigo.

Emissores são ou cooperadores ou trapaceiros. A probabilidade de que um emissor seja um cooperador é de 0,9. No primeiro movimento do jogo, a Natureza determina qual é o tipo de emissor,que aprende qual é seu tipo e escolhe entre fazer uma saudação ou não. O receptor inicialmente não sabe o tipo de cidadão que está emitindo o sinal, mas sabe sobre a distribuição dos tipos. O receptor observa se o emissor o saúda ou não e, então, decide cooperar com ele ou rejeitá-lo. Se o receptor rejeita o emissor, todos recebem $\$ 0$. Se o receptor cooperar e o emissor for um trapaceiro, o emissor trapaceará o receptor, obtendo um ganho (\$2) e, do outro lado, o receptor suportará uma perda (-\$2). Se o receptor cooperar e o emissor for um cooperador, ambos irão estabelecer uma relação de cooperação mútua e de longo prazo, da qual obterão um fluxo de ganhos isolados relativamente baixos, mas que se tornam altos quando agregados ( $\$ 6$ para cada um). Tecnicamente, o mesmo fluxo de pagamentos é acessível para o trapaceiro e para o cooperador, mas, porque ambos têm taxas de desconto diferentes, ${ }^{13}$ o trapaceiro estabelecerá seu valor em menos de \$2 (o ganho pela desistência) e o cooperador determinará seu valor em $\$ 6$. Custa $\$ 3$ para ambos os emissores saudarem a bandeira e $\$ 0$ para não saudar a bandeira.

Uma situação de "equilíbrio diferenciador" (separating equilibrium) ocorre sob as seguintes condições. O receptor acredita que qualquer um que saúde a bandeira é um cooperador e qualquer um que não o faça é um trapaceiro. Conseqüentemente, o receptor coopera com todos aqueles que saúdem a bandeira (na expectativa de obter um ganho de $\$ 6>\$ 0)$ e rejeita qualquer um que não saúde a bandeira $(\$ 0<-\$ 2)$. O cooperador recebe $\$ 3$ por saudar a bandeira $(\$ 6-\$ 3)$, valor que excede seu ganho caso ele deixasse de saudá-la $(\$ 0)$. O trapaceiro recebe $\$ 0$ quando deixa de saudar a bandeira, valor que excede o benefício que obteria caso a saudasse ( $\$ 2-\$ 3=-\$ 1)$. Portanto, nenhum emissor se desvia de sua estratégia. O receptor não tem razões para revisar sua suposição de que todos aqueles que saúdam a bandeira são cooperadores, pois, em estado de equilíbrio, isso é verdade. Este equilíbrio é um equilíbrio bayesiano perfeito. ${ }^{14}$

Outro equilíbrio bayesiano perfeito é o “agrupamento passivo”, a saber, um equilíbrio por agrupamento pelo qual ninguém emite o sinal. Suponha-se que ninguém saúde a bandeira e que o receptor estime, corretamente, a proporção de cidadãos de tipo superior e inferior em uma população dada. O receptor cooperará com todos, desde que seus ganhos $(.9(\$ 6)+.1(\$ 2)=\$ 5.2)$ excedam os ganhos decorrentes da 
ação de rejeitar a todos $(\$ 0)$. Neste caso, nem o cooperador ( $\$ 6>\$ 6-\$ 3)$ nem o trapaceiro $(\$ 2>\$ 2-\$ 3)$ saudarão a bandeira. Não importa em que o receptor fora do estado de equilíbrio acredita: mesmo que ele pense que apenas os cooperadores saúdam a bandeira, nenhum emissor ganha nada fazendo isso. Conseqüentemente, o agrupamento passivo é um equilíbrio bayesiano perfeito.

O “agrupamento ativo”, no qual todos emitem o sinal, não é um equilíbrio bayesiano perfeito: o trapaceiro se sai melhor esquivando-se ou deixando de saudar $(\$ 0)$ do que saudando a bandeira $(\$ 2-\$ 3=-\$ 1)$, mas pode-se criar um equilíbrio por agrupamento ativo ajustando os números. Suponha-se que o trapaceiro ganhe $\$ 4$ com o ato de cooperar; suponha-se também que o emissor acredite que é de $90 \%$ a possibilidade de que aquele que saúda a bandeira seja um cooperador. Suponha-se também que o receptor creia ser sempre um trapaceiro aquele que não saúda a bandeira. Se todos saudarem a bandeira, o receptor preferirá cooperar a rejeitar $(.9(\$ 6)+.1(-$ $\$ 2)=\$ 5.2>0$ ). O cooperador não se desviará do comportamento adotado: o ganho por sinalizar $(\$ 6-\$ 3=\$ 3)$ excede o ganho por não sinalizar $(\$ 0)$. O trapaceiro também não se desviará $(\$ 4-\$ 3=\$ 1>\$ 0)$.

Há muitos outros estados de equilíbrio possíveis, incluindo-se o equilíbrio no qual as pessoas de um tipo escolhem aleatoriamente entre sinais. Para manter a discussão mais simples, evitarei esses temas. ${ }^{15} \mathrm{O}$ exemplo é suficiente para meus propósitos, que são analisar o efeito da intervenção legal nos comportamentos simbólicos. Por ora, me concentrarei em três tipos de intervenção legal (uma quarta será introduzida na próxima seção).

Mudanças nos custos de sinalização. Consideremos nosso exemplo original. Suponha-se que o custo de saudar a bandeira caia para \$1 para os dois tipos de emissores. O trapaceiro, agora, receberá $\$ 1$ por saudar a bandeira $(\$ 2-\$ 1=\$ 1>\$ 0)$, assim, as estratégias de diferenciação não mais constituem um equilíbrio bayesiano perfeito. Estados de equilíbrio por agregação, ativo e passivo, são agora possíveis. O equilíbrio passivo é possível, pois, quando os dois tipos de cidadãos deixam de saudar a bandeira, o receptor coopera mesmo assim $(\$ 5.2>\$ 0)$. Desse modo, nenhum dos tipos de cidadão recebe o suficiente para diferenciar-se como cooperador e o custo do sinal não se justifica $(\$ 6>\$ 5, \$ 2>\$ 1)$. O equilíbrio ativo também é possível, pois, quando os dois tipos de cidadãos saúdam a bandeira e o receptor acredita que todos aqueles que não emitem o sinal são trapaceiros, nenhum dos tipos ganha nada por deixar de saudar a bandeira; ser percebido como trapaceiro e ser rejeitado pelo receptor $(\$ 5>\$ 0, \$ 1>\$ 0)$.

Mudanças nos ganhos de cooperação dos receptores e dos emissores. Na discussão do equilíbrio por agregação ativo, vimos que um crescimento de $\$ 2$ para $\$ 4$ nos ganhos de um trapaceiro em razão de sua cooperação é capaz de sustentar um equilíbrio por agregação ativo. Em geral, quanto maiores os ganhos do emissor com a cooperação (em relação à sua rejeição), maiores os incentivos para emitir o sinal e evitar ser identificado como 
trapaceiro e rejeitado. Do mesmo modo, se o ganho de um receptor em razão de sua cooperação com um trapaceiro for reduzido em um montante suficiente, a agregação ativa ou passiva não mais estará em equilíbrio.

Mudanças nas crenças do receptor sobre as quantidades de tipos de cidadão. Suponha que haja um equilíbrio passivo por agregação no qual ocorre cooperação. Vimos que isso é possível com os números utilizados no primeiro exemplo; e o resultado continua a se sustentar se os ganhos do emissor em decorrência da cooperação com o trapaceiro forem ainda menores do que os mencionados no exemplo original, digamos, $-\$ 6$. Suponha que um choque faça os receptores acreditarem que $60 \%$, e não apenas $10 \%$, de todos os emissores são trapaceiros. Como reação, os receptores irão recusar-se a cooperar quando os tipos de cidadão não puderem ser diferenciados $(.4(\$ 6)+.6(-$ $\$ 6)=\$ 1.2<\$ 0)$. Nesta situação, os cooperadores irão desviar-se de seu comportamento e saudarão a bandeira $(\$ 6-\$ 3>\$ 0)$. Os trapaceiros não se desviarão $(\$ 0>\$ 2-\$ 3)$. Como resultado, um equilíbrio diferenciador se formará. Os receptores não corrigirão suas crenças no futuro: como eles cooperam apenas com aqueles que saúdam a bandeira, e todos aqueles que saúdam a bandeira são cooperadores, eles não aprenderão a quantidade correta de tipos de cidadão.

\section{I.2 O EMPRESÁRIO NORMATIVO ${ }^{16}$}

O jogo de cooperação requer que os sinais custem, mas nada no jogo determina a forma do sinal. Desde que uma ação seja, aparentemente e de fato, custosa, ela pode servir de sinal de que o emissor pertence ao tipo superior de cidadão. Como notamos acima, dar presentes, fazer propaganda, comprar produtos que estejam na moda e outras formas de desperdício podem servir como sinais no jogo de cooperação, mas os sinais podem ser ambíguos. Dar um presente ou assistir a uma parada não revela a taxa de desconto de uma pessoa se ela aprecia tais atividades. A questão é, portanto, como certos comportamentos ganham valor simbólico?

Uma resposta aproxima-se da idéia de pontos focais (SCHELLING, 1958, p. 203-264). Coincidência histórica, qualidades físicas e outros atributos podem levar as pessoas a associar um comportamento a certas qualidades de caráter. Por exemplo, o dia 19 de abril ${ }^{17}$ tornou-se, meramente por acaso, a data em que um oponente do governo pode distinguir-se por explodir um prédio ou realizar outras formas de protesto, características da extrema direita. Os eventos ocorridos nesta data, por mera coincidência, conferiram-lhe destaque.

Outros sinais são fabricados. O dia de Martin Luther King, por exemplo, foi criado pelo governo federal: ele não emergiu espontaneamente. Uma vez criado, as pessoas puderam sinalizar sua lealdade ao movimento dos direitos civis, fazendo, neste dia, gestos públicos e visíveis para mostrarem seu respeito.

Sinais verdadeiramente fabricados são raros. Usualmente, quando o governo ou agentes privados conseguem estabelecer certas ações como sinais, eles o fazem 
chamando a atenção pública para um ou vários pontos focais conflitivos. Para mostrar respeito aos direitos civis deve-se dispor de um feriado ou outra celebração. Ela deve ser em honra de King ou de outro líder? Ela deve coincidir com a morte de King, com seu nascimento ou com a data de um de seus feitos? A história nos fornece um bom número de pontos focais; indivíduos dotados de autoridade abrem espaço para os cidadãos organizarem-se em torno deles.

Situemos o jogo de cooperação, ou jogo do patriotismo, em um jogo mais amplo para analisar esses pontos formalmente. Antes mesmo do primeiro movimento do jogo, um empresário normativo anuncia que uma ação em particular será um símbolo. Ele afirma que uma certa ação, por exemplo, a de votar, será compreendida como sinal da propensão para cooperar. O jogo de cooperação resta modificado da seguinte forma. Cada emissor escolherá entre todos os sinais possíveis. Pode escolher o sinal recomendado pelo empresário normativo ou outros sinais. Depois de finalizado o jogo de cooperação, o empresário normativo obterá ganhos, cujo montante variará em função do número de pessoas que emitirem o sinal recomendado por ele. Em alguns contextos, faz sentido afirmar que ele receberá seu ganho se eliminar um equilíbrio agregador ativo; em outros contextos, faz sentido dizer que a recompensa virá de sua capacidade de transformar um equilíbrio agregador passivo em um equilíbrio diferenciador. $\mathrm{O}$ empresário normativo não tem, ex ante, informações perfeitas sobre os ganhos das partes no jogo de cooperação, portanto, não será capaz de escolher, sempre, o sinal capaz de maximizar seus ganhos. Entretanto, em razão da repetição do jogo, o empresário normativo pode elaborar novos sinais nas futuras partidas, se os sinais iniciais falharem em obter os maiores ganhos.

Ao escolher entre os sinais disponíveis, os emissores têm apenas uma vaga idéia de quais sejam os sinais capazes de diferenciá-los dos trapaceiros. Por isso, vamos supor que eles não saibam quais os ganhos do receptor e quais os custos e ganhos do emissor. Os emissores devem se preocupar se o receptor reconhecerá no sinal um esforço de diferenciação ou apenas a realização de um comportamento agradável. Este é um problema de coordenação: tais comportamentos poderão funcionar como sinais se todos, ou a maior parte das pessoas, acreditarem que certos comportamentos funcionam como sinais e, além disso, que eles tenham, de fato, a estrutura de custo adequada. Os emissores vão se fiar nos costumes (por exemplo, dar presentes), mas também nos sentidos fornecidos pelo Zeitgeist ${ }^{18}$ (por exemplo, o anticomunismo): as sugestões de empresários normativos autorizados diminuem o espectro das possibilidades. Se um número suficiente de emissores resolver seguir as sugestões de uma determinada pessoa, ela se tornará um autêntico empresário normativo (uma condição importante para isso é a notoriedade: por esta razão, mesmo celebridades politicamente ignorantes podem fazer declarações influentes, política e culturalmente, além disso, os herdeiros da realeza, independentemente de suas habilidades, sempre podem encontrar seguidores). 
A importância do jogo EN, ${ }^{19}$ como passo a me referir a ele a partir de agora, é mostrar que, se um sinal não for capaz de criar um equilíbrio diferenciador ou um equilíbrio agregador ativo, o empresário normativo é incentivado a criar um novo sinal na esperança que ele seja bem-sucedido. Deve-se enfatizar também que a sinalização pode emergir espontaneamente, em função de eventos aleatórios que se tornam focais (como o dia 19 de abril) sem que empresários normativos exerçam nisso papel algum. Em ambos os casos, vamos utilizar a expressão transformações simbólicas para nos referirmos à criação de novos símbolos para substituir aqueles que falharam na produção do estado de equilíbrio apropriado.

Sendo mais realista: muitas pessoas, inclusive políticos estabelecidos, acadêmicos, escritores, jornalistas e outros agentes culturais, competem, no primeiro movimento do jogo EN, pela posição de um empresário normativo de sucesso. Eles propõem sinais; os cooperadores usam o sinal que aparenta ser o mais adequado para criar um equilíbrio diferenciador. Haverá conflito e confusão; no entanto, desse estado pode nascer uma agregação de participantes junto a um sinal e este fato gera benefícios que fluirão na direção do empresário normativo que o propôs.

Podemos acrescentar agora uma quarta alternativa aos três métodos utilizados para influenciar o equilíbrio da sinalização. Quando o Estado ou um empresário normativo privado for bem-sucedido em tornar um sinal público, as pessoas podem substituir sinais antigos pelo novo e este pode alterar o estado de equilíbrio.

\section{3 Por Que Patriotismo?}

Diferentes de sinais como dar presentes e fazer propaganda, sinais patrióticos fazem apelo a valores nacionais. No entanto, a diferença entre ambos os tipos de ação é superficial. Ações podem ser interpretadas como sinal do desejo de cooperar se tiverem alguma conexão com o bem-estar do receptor. Quando o grupo de jogadores for composto de pessoas envolvidas em relações sociais ou de negócios, os sinais consistirão, tipicamente, em ações que apelam aos prazeres e interesses dos membros do grupo,que, muitas vezes, são muito idiossincráticos e locais (churrascos, viagens de pesca, confraternizações, rituais e banquetes, trocas de presentes e assim em diante). Quando o grupo de jogadores consistir em uma nação, as ações devem ser tênues, ou seja, não devem causar ofensas ou custos significativos para a maior parte das pessoas. Nessas circunstâncias, será possível encontrar dois tipos de comportamento simbólico: símbolos “puros”, como saudar a bandeira, cujos benefícios são completamente imateriais; e símbolos "impuros", como votar e discriminar os inimigos do estado, que produzem bens públicos benéficos a todos ou à maior parte dos cidadãos. Pode-se dizer que os símbolos "impuros" são mais focados no seguinte sentido: todos reconhecem como patriota alguém que se sacrifique pelo seu país. Já os símbolos “puros" precisam de um esforço concertado para criar ou disseminar uma tradição compreensível por todos. 
Um exemplo estilizado pode nos ajudar a explicar por que demonstrações de patriotismo podem servir como sinais. A era McCarthy ${ }^{20}$ surgiu de repente, depois da explosão de uma bomba de hidrogênio pela União Soviética e da exposição pública da existência de espiões soviéticos no governo dos Estados Unidos da América, eventos que aumentaram o medo relativo à segurança do país e geraram preocupação sobre a coesão nacional. Diante de fatos como esses, mesmo em negócios cotidianos e relações sociais muito distantes dos eventos internacionais, os cidadãos passaram a desconfiar que qualquer pessoa engajada em ações capazes de enfraquecer, ainda que remotamente, a segurança do país poderia ser um trapaceiro. Afinal, os trapaceiros preferem ganhos de curto prazo a recompensas de longo prazo e o declínio de um país é, normalmente, um processo lento e insidioso. No entanto, não devemos presumir que as pessoas deixem de confiar umas nas outras, mesmo naquelas pessoas consideradas um perigo remoto à segurança global do país, para realizar ações como: entregar pequenos objetos ou ajudar a consertar uma nova cerca. É suficiente presumir que alguns prestarão atenção à sua própria lealdade, evitando ostensivamente (ou relegando ao ostracismo) pessoas que realizem ações passíveis de serem interpretadas como não-patrióticas; pouco importando o quão insignificantes ou inofensivas elas sejam. Caso sejam bem-sucedidos, todos aqueles que desejam evitar ser considerados trapaceiros se reunirão ao redor dessas ações, inclusive o ostracismo de pessoas consideradas trapaceiras, produzindo-se, como resultado, uma grande conformidade a normas supostamente patrióticas.

Com o crescimento da ameaça soviética, as pessoas sentiram que podiam se diferenciar dos trapaceiros recusando-se a criticar o governo (ao menos sua ala militarista), engajando-se em manifestações patrióticas ostensivas, levantando suspeitas sobre imigrantes e outros, cuja conexão com os Estados Unidos da América tivesse sido atenuada, e criticando aqueles que criticam os valores do país, especialmente os partidários da ideologia comunista da União Soviética.

Note-se que o significado dos eventos mundiais foi duplo. Primeiro, eles forneceram o ponto focal, sugerindo, portanto, a forma do sinal. Se a União Soviética é a ameaça e é controlada por comunistas, os comunistas norte-americanos também podem ser uma ameaça. Evitar comunistas norte-americanos revela o comprometimento com os cidadãos não-comunistas. Segundo, os eventos mundiais podem ter aumentado a percepção da necessidade de evitar trapaceiros. Em tempos de paz, estabelecer uma relação com um trapaceiro pode não ser algo tão perigoso: eles podem trapacear você, mas, de qualquer maneira, pouca coisa está em jogo. Em tempos de guerra, estabelecer uma relação com um trapaceiro é perigoso: ao trapacear alguém, o trapaceiro faz com que o trapaceado fique vulnerável à escassez crescente da economia de guerra e também, quem sabe, a poderes hostis. McCarthy, um empresário normativo clássico, explorou esses medos. Ele não 
fabricou a associação entre comunismo e subversão, mas forneceu teorias e "evidências" para fortalecer as suspeitas. Antes da era McCarthy, evitar comunistas não era um sinal forte de lealdade. Durante a era McCarthy, evitar comunistas tornouse um sinal de lealdade tão forte que foi criado um equilíbrio diferenciador. Somente após alguns anos esse estado de equilíbrio se desfez, quando se passou a acreditar que a ameaça soviética era exagerada, que a ameaça dos trapaceiros era exagerada ou que era muito alto o custo de relegar injustamente ao ostracismo pessoas que não eram trapaceiros. Como resultado, deixou de ser vantajoso para todos incorrer no custo de emitir um sinal patriótico, pois seria possível obter ganhos semelhantes emitindo ou não o sinal e, além disso, o equilíbrio diferenciador se converteu em um equilíbrio agregador no qual ninguém (ou poucos) emitia mensagens patrióticas e ninguém (ou poucos) admitia que, por não emitir tais mensagens, uma determinada pessoa não seria um parceiro confiável. ${ }^{21}$

\section{I.4 Pressuposições E Qualificações}

Emissores e receptores. Um aspecto pouco elegante do modelo é a divisão da população entre receptores e emissores, quando, de fato, todos os indivíduos são receptores e emissores. O raciocínio é o seguinte: quando alguém decide sinalizar ou não, toma o resto da população como dada. O receptor pode ser considerado o cidadão médio com o qual o emissor espera lidar, dado que, em toda sociedade funcional, a maior parte da população é de cooperadores e apenas uma pequena fração é de trapaceiros. A artificialidade dessas suposições pode ser evitada com a utilização de um modelo de coordenação no qual todos emitem e recebem sinais, ${ }^{22}$ no entanto, um modelo como este produz uma complexidade desnecessária.

Trapaceiros. Alguém pode ganhar pouco ao cooperar porque tem uma alta taxa de desconto, mas também porque não deseja o que os outros podem oferecer-lhe ou porque os outros pedem dele, como sinal de sua disposição para cooperar, uma ação que ele julga custosa demais. Assim, o comunista comprometido ou o liberal por princípio pode se recusar a mostrar respeito à bandeira ou a realizar ações supostamente patrióticas porque ele ou ela acredita que um cidadão realmente cooperativo ou patriótico apontará as deficiências do sistema político. A diferença entre um trapaceiro e, digamos, um liberal por princípio é crucial: o segundo não se preocupa com o futuro, já o primeiro importa-se com o futuro, mas acredita que o comportamento simbólico que se requer dele é repugnante. Os dois tipos são agregados pelo cooperador, convencido do valor do sinal. Voltaremos em seguida a este problema: a crueza dos sinais. ${ }^{23}$

A razão para sinalizar: a recompensa pela cooperação privada. O modelo da cooperação e do patriotismo pressupõe que os cidadãos emitam sinais, inclusive sinais com significado político, para induzir os outros a cooperarem com eles. Outro propósito para a emissão de sinais políticos é revelar convicções para o governo e outros 
cidadãos com o fim de influenciar a decisão dos primeiros e o voto dos segundos. ${ }^{24}$ Uma terceira possibilidade é revelar o custo de alguém para os competidores em potencial. ${ }^{25}$ Tais motivos podem ser importantes, mas, para simplificar a exposição, vou ignorá-los.

Note-se que é melhor pensar nos receptores cooperando mais ou menos com os cidadãos do que imaginar uma escolha do tipo "ou tudo ou nada".

Tipos e ações discretas versus tipos e ações contínuas. Um modelo alternativo pode supor que as pessoas se enquadrem em uma série de tipos contínuos. Apenas alguns serão supertrapaceiros ou supercooperadores e o resto se agrupará em uma posição moderada. Este modelo também pode supor que as pessoas emitam uma série de sinais patrióticos ou cooperativos, do mais barato ao mais caro. Um modelo que parta desses pressupostos não chegará a conclusões diferentes de um modelo dicotômico, mesmo levando-se em conta que um modelo assim ainda não foi bem desenvolvido pela literatura. Um aspecto positivo de um modelo não-dicotômico seria sua capacidade de mostrar como preferências contínuas resultam em comportamentos descontínuos; resultado obtido artificialmente em um modelo dicotômico. O resultado seria mais convincente por sugerir que o comportamento das pessoas nunca é completamente adequado aos padrões; elas são sempre influenciadas pelo conformismo dos outros. ${ }^{26}$ Esse resultado é consistente com a observação do comportamento; sua importância será discutida adiante. ${ }^{27}$

\section{REgULAÇÃO ESTATAL DO COMPORTAMENTO SIMBÓLICO}

Podem-se distinguir dois efeitos possíveis resultantes da proibição pelo governo de comportamentos como queimar a bandeira. Primeiro, a lei pode ter algum efeito sobre o comportamento; aumentar ou diminuir a ação de queimar a bandeira. Chamamos esse efeito de efeito comportamental da lei. Segundo, a lei pode ter algum efeito sobre a percepção das pessoas sobre o comportamento que ela pretende influenciar. Por exemplo, aqueles que continuam a queimar a bandeira serão considerados não-patriotas. Antes da lei, eles eram reputados não muito patriotas ou apenas estranhos. De outro lado, aqueles que continuam a queimar a bandeira podem passar a ser tidos como libertários; antes da lei, eram considerados não-patriotas. O efeito da lei sobre a crença de alguém a respeito de uma pessoa que adota um certo comportamento será chamado de efeito hermenêutico.

O jogo de cooperação mostra as diversas maneiras pelas quais podem ser gerados efeitos comportamentais e hermenêuticos. Mencionamos acima quatro métodos. Primeiro, a lei pode mudar o custo de enviar um sinal. Segundo, ela pode modificar as recompensas resultantes da cooperação. Terceiro, ela pode mudar as crenças sobre a proporção de tipos de cidadão no total da população. Quarto, a lei pode modificar a recompensa de um empresário normativo em construir um sinal ou pode construir 
um sinal ela mesma. Os quatro efeitos juntos podem produzir uma mudança no equilíbrio; o comportamento das pessoas nesse novo estado de equilíbrio representa o efeito comportamental da lei; as crenças nesse equilíbrio representam o efeito hermenêutico da lei.

Os exemplos seguintes ilustram esses fenômenos. Não farei esforços de sistematização, mas os exemplos tratarão de diferentes aspectos dos modelos. A parte IV juntará todos os fios.

\section{I BANDEIRAS}

Uma maneira de mostrar-se cooperativo é demonstrar respeito pela bandeira. Chamarei de "saudar a bandeira" uma série de comportamentos, inclusive o de saudar a bandeira quando a oportunidade se apresente: exibir a bandeira, especialmente quando isso envolver rituais complexos etc. Chamarei de "desrespeito à bandeira" qualquer gesto percebido como desrespeitoso à bandeira: desde ignorar a bandeira em ocasiões em que se exige respeito a ela até o ato de queimá-la nas portas do tribunal. Saudar a bandeira é uma ação custosa. Embora o custo de saudar a bandeira seja o mesmo para cooperadores e trapaceiros, os primeiros percebem maiores ganhos ao emitirem esse sinal, pois os receptores não cortarão relações com eles ao descobrirem que tipo de cidadão eles são, no entanto, romperão relações com os trapaceiros. O jogo de cooperação demonstra porque o entusiasmo pela bandeira aumenta ou diminui. Em tempo de crise, o risco do ostracismo é tão grande que ninguém se arriscará a ser punido por se desviar do comportamento vigente no estado de agrupamento ativo. Em tempos seguros, os receptores cooperarão com qualquer um, pois perdem pouco ao deixar de cooperar com os trapaceiros. Assim, os trapaceiros não precisam se preocupar em saudar a bandeira. Em tempos de tensão, um equilíbrio diferenciador pode se instalar se os cooperadores acharem vantajoso saudar a bandeira.

Faz sentido que os receptores acreditem que todo aquele que não saúda a bandeira é um parceiro não-cooperativo? Sim e não. Sim, pela associação desse comportamento com os soldados que lutam e morrem pela bandeira em uma guerra justa. Por se sacrificarem para o bem da nação, os soldados são considerados os cooperadores por excelência. Não, porque lutam pela bandeira (e não, por exemplo, pelo rei) e a bandeira é (diga-se) apenas uma maneira de identificar a propriedade de um certo país. Também porque a bandeira é associada a um governo em particular, não à nação, e esse governo é desprezado. Por isso, em vários países, é ridícula tanto a idéia de que a bandeira é sagrada quanto a idéia de queimá-la. De fato, queima-se a bandeira apenas nos Estados Unidos da América. Nesse país, a bandeira tornou-se um ponto focal de cooperação em nível nacional (símbolo de patriotismo) em razão de contingências e tradições que não existem em nenhum outro país.

Todos os equilíbrios citados acima podem ser desejáveis ou não, pois saudar a bandeira é um sinal imperfeito da propensão de cooperar. Consideremos o equilíbrio 
diferenciador. Alguns mostrarão respeito pela bandeira para obter ganhos decorrentes da cooperação, mas trapacearão quando a oportunidade se apresentar. Outros decidirão não mostrar respeito à bandeira por entenderem que um patriota de verdade não deve realizar esse tipo de ação; assim, os ganhos de cooperação resultantes da relação com essas pessoas serão perdidos. O equilíbrio se sustentará enquanto o percentual de erro for baixo o suficiente para que os receptores continuem a ganhar ao cooperar apenas com aqueles que saúdem a bandeira. Saudar a bandeira não será um sinal confiável de patriotismo se todos o fizerem para evitarem ser rejeitados e se for crença geral que fazê-lo não é garantia de patriotismo. Em uma situação como essa, será fácil perceber que alguns trapaceiros saúdam a bandeira. A ação torna-se um ritual vazio, fato que pode levar os cooperadores, com o tempo, a abandonar o sinal e o empresário normativo a criar outros (em um exemplo de transformação simbólica).

O Estado, considerado fator exógeno, pode influenciar a ação de saudar a bandeira de várias maneiras. Pode mudar o custo de saudar a bandeira. Considere-se uma lei que não apenas torne ilegal queimar a bandeira, mas que também exija dos cidadãos que mostrem respeito a ela de várias maneiras (uma lei que apenas banir o ato de queimar a bandeira não imporá qualquer custo à maioria da população: sua importância será discutida na Parte IV.C.). Suponha-se que, antes de a lei ser aprovada, exista um estado de equilíbrio diferenciador. Cooperadores mostram respeito pela bandeira e trapaceiros corrompem-na e chegam a queimá-la. A lei diminui o custo de saudar a bandeira aumentando o custo de corrompê-la ou ignorá-la. É plausível que essa ação crie um estado de equilíbrio agregador ativo. Porque emitir o sinal, agora, torna-se tão custoso, os trapaceiros tenderão a imitar os cooperadores e emitirão o sinal.

Mas a lei pode ter um efeito diverso sobre o comportamento. Quando aumenta o custo de não emitir o sinal, o receptor pode antecipar que todos - cooperadores e trapaceiros - respeitarão à bandeira. Se for este o caso, os receptores não poderão mais confiar neste sinal para identificar o tipo de cidadão com o qual estão lidando. Se as perdas suportadas pelo receptor ao cooperar com um trapaceiro forem altas o suficiente, ele se recusará a cooperar com qualquer um que possa suportar o custo de saudar a bandeira. Se os emissores forem capazes de antecipar tal reação, deixarão de se preocupar em saudar a bandeira, mesmo que a lei tenha reduzido o custo de tal ação. Por que ter esse custo se o receptor não cooperará? Desse modo, a lei produz um equilíbrio agregador passivo em que ninguém mostra respeito pela bandeira e ninguém coopera com ninguém.

É impossível prever o efeito comportamental de uma lei: ela pode aumentar ou diminuir o grau de respeito pela bandeira. Um defensor do desrespeito à bandeira pode argumentar que o objetivo da lei é mudar as crenças, e não o comportamento: instilar nas pessoas o sentimento de respeito à bandeira. No entanto, também é impossível prever o efeito hermenêutico de uma lei. O respeito à bandeira aumentará se as pessoas 
acreditarem, mais e mais, que apenas cooperadores mostram respeito à bandeira. Se o status quo é um equilíbrio passivo e se a lei criar um equilíbrio diferenciador, ela pode levar as pessoas a abandonar a crença de que todos os que saúdam a bandeira são estranhos ou idiossincráticos. Nessas circunstâncias, a lei vai levá-las a crer que tais pessoas são cooperadores e patriotas. A lei pode falhar, do mesmo modo, se o status quo for um equilíbrio diferenciador e seu objetivo for aumentar o respeito à bandeira. Se ela produzir um equilíbrio agregador passivo, as pessoas deixam de se associar para saudar a bandeira com qualquer tipo de cidadão. Se ela produzir um equilíbrio agregador ativo, todos passam a crer que qualquer um que saúde a bandeira é um cooperador ou um trapaceiro. Denominamos este fenômeno de reificação. Neste caso, a lei torna ambíguo o sentido do símbolo em vez de aumentar o respeito por ele. Se o objetivo da lei for aumentar o respeito pela bandeira, nesse caso, ela será considerada autofrustrante.

Deve-se evidenciar a complexidade de prever o efeito de uma lei que trate da queima de bandeiras sobre os comportamentos e as crenças. Deve-se desconfiar de qualquer afirmação que preveja este ou aquele efeito socialmente desejável como decorrente de uma lei como essa. Se o que dizemos é verdade, por que há tanto apoio nos Estados Unidos da América a uma lei contra a queima de bandeiras? Responderemos a esta questão na Parte 4.3.28

\subsection{Autocensura}

A autocensura, como o respeito à bandeira, pode emergir como um sinal da propensão a cooperar. Com o objetivo de serem identificadas como cooperadores, algumas pessoas chamam a atenção sobre seu apoio ao governo e acusam os críticos de trapaceiros. Assim, atribuem ao comportamento de apoiar o governo o sinal de patriotismo. O cidadão médio gosta de criticar o governo ou vê nisso uma obrigação, portanto, deixar de criticar será, normalmente, uma ação custosa. Os cooperadores poderão recuperar o custo que tiveram por meio da cooperação com os receptores; os trapaceiros não poderão fazê-lo. A combinação entre autocensura e patriotismo aparece freqüentemente nos países em virtude, certamente, de uma tradição de autocensura e deferência em relação à autoridade e, em parte, sem qualquer dúvida, em razão das ameaças em tempo de guerra que ganham a forma de conflitos destrutivos pela preservação nacional. Os empresários normativos, normalmente, exploram tais oportunidades.

A diferença entre a autocensura e o respeito à bandeira diz respeito apenas à estrutura de custo de ambas as ações. Alguns podem achar a autocensura mais custosa, outros, o respeito à bandeira. De qualquer modo, se uma das ações ou ambas emergirão como sinais da propensão a cooperar, isso depende dos diversos custos com que ambos os tipos de cidadão se depararão, ainda, com a influência da tradição e de outras circunstâncias capazes de contribuir para a transformação de uma ação em um ponto focal. 
O problema de um estado de equilíbrio com autocensura é que ele diminui o bem-estar da população. Este ponto é desenvolvido por Timur Kuran em um livro recente, ${ }^{29}$ portanto, serei breve. Quando os custos referentes à reputação forem suficientemente altos, tanto trapaceiros quanto cooperadores sérios que se importem profundamente com o Estado, mas que discordem da opinião prevalente, podem evitar criticar o governo e, assim, informações valiosas serão perdidas. ${ }^{30} \mathrm{Na}$ era McCarthy, momento em que o custo de criticar o governo (e, em qualquer proporção, McCarthy e as políticas que ele apoiava) era extremamente alto, muitos (trapaceiros e cooperadores) deixaram de criticar o governo. Nessas circunstâncias, a possibilidade de criticar em nome do patriotismo foi perdida, ação de alto valor social e, além disso, desapareceu a (eventual) possibilidade de expor os trapaceiros.

Um dos aspectos mais impressionantes do McCarthismo foi sua ação de empresário normativo, capaz de alterar pontos focais sem modificar a lei, mas pode-se examinar também o efeito da lei, por exemplo, que institui a censura. Imaginemos uma situação de equilíbrio agregador passivo: ninguém pratica a autocensura. $\mathrm{O}$ Estado cria uma lei que institui a censura. Se a lei for dotada de sanções em intensidade adequada, será criado um estado de equilíbrio diferenciador. A lei terá dois efeitos que se devem notar: revela os trapaceiros (efeito interno) e desencoraja a crítica ao governo (efeito externo). Isso caracteriza todas as leis de que estamos tratando. A lei que protege a bandeira expõe os trapaceiros e encoraja o respeito à bandeira. Uma lei que institua a censura pode ser mais eficiente em expor os trapaceiros do que outra que proteja a bandeira; no entanto, terá mais efeitos sociais maléficos do que a última. Afinal, o discurso público tem efeitos sociais positivos ausentes do ato de mostrar respeito à bandeira.

O Estado pode produzir ou manter estado de equilíbrio diferenciador ou agregador ativo, influenciando a crença dos receptores sobre a fração de trapaceiros na população total. Suponha-se que os receptores acreditem que quase todos os cidadãos são cooperadores e, por isso, cooperem com qualquer um; assim ninguém emite o sinal que consiste em não criticar o governo. O governo intervém para alertar que vários cidadãos são, de fato, trapaceiros. Se o governo for persuasivo, os receptores deixarão de aceitar novos parceiros cooperativos (sendo mais realista, eles tomarão medidas para diminuir os ganhos dos emissores). A reação dos cooperadores será tentar diferenciar-se dos trapaceiros emitindo o sinal, ou seja, deixando de criticar o governo. Se os trapaceiros não conseguirem recuperar suas perdas, eles não imitarão os cooperadores, assim, será criado de um estado de equilíbrio diferenciador. Os receptores não terão elementos para revisar suas crenças, mesmo sabendo que são imprecisas, afinal, apenas cooperando com alguém será possível descobrir que tipo de cidadão aquela pessoa realmente é.

Pode-se analisar a propaganda de outra maneira. No jogo EN, o Estado pode assumir o papel de empresário normativo fazendo propaganda. Com isso, cria a 
oportunidade para que os cidadãos emitam sinais de patriotismo ou subversão. $\mathrm{O}$ sinal é a autocensura: resistir ao impulso de discordar da propaganda. Quanto mais abertamente mentirosa for a propaganda, mais evidente será o sinal emitido por alguém que resista a discordar dela. As mentiras oficiais funcionam aqui como a bandeira ou como um feriado nacional: oferecem a oportunidade para demonstrar lealdade ao governo.

\subsection{Votar E OUTRAS FormaS de PARTICIPAÇÃo EM ATIVIDAdeS CÍVICAS}

As teorias da escolha racional não conseguem explicar satisfatoriamente por que as pessoas votam. Poder-se-ia esperar que ninguém votasse diante da pequena possibilidade de um eleitor individual influenciar o resultado da eleição, além do custo relativamente alto de gastar tempo de trabalho esperando em uma fila para votar em uma cabine. Afirmar um "gosto" por votar transforma o problema em uma tautologia: outros esforços para lidar com funções utilitárias não foram bem-sucedidos. ${ }^{31}$ Pode-se pressupor a existência de uma norma social que exige o ato de votar, ${ }^{32}$ mas essa estratégia intelectual apenas transforma a questão "por que as pessoas votam?" na questão "por que existe uma norma social que exige que as pessoas votem?".

Tentar elaborar uma teoria adequada para explicar o voto nos levaria para além dos limites deste texto, mas podemos esboçar alguns de seus contornos. O sinal é votar na cabine, e não votar neste ou naquele candidato. Votar é uma ação observável, mas o ato de definir o voto não é: amigos, sócios e familiares ficam sabendo que votamos porque saímos do trabalho ou simplesmente porque contamos para eles em uma situação em que mentir é um risco para nossa reputação. $\mathrm{O}$ ato de votar é custoso tanto para cooperadores quanto para trapaceiros, mas os primeiros recuperam seus custos em várias rodadas de cooperação com o receptor; o trapaceiro não. Em um estado de equilíbrio diferenciador, todo votante é considerado um cooperador e os não-votantes, trapaceiros. Essa explicação chama atenção para o paradoxo envolvido na ação de votar: votar funciona como um sinal, pois os custos envolvidos em realizar tal ação são maiores do que os ganhos materiais decorrentes dela. Se votar fosse lucrativo, ou seja, se as pessoas fossem pagas para votar ou severamente punidas se não o fizessem, ou ainda, se todos derivassem "utilidades expressivas" desse ato, tanto cooperadores quanto trapaceiros votariam. De acordo com a teoria que estamos expondo, o ato de votar não está ligado a um gosto, ao desejo de se expressar ou de ajudar o país (embora saibamos que esses três motivos reforçariam o incentivo patriótico para que as pessoas votassem), mas de obter ganhos decorrentes da cooperação com outros agentes privados. O patriotismo é relevante apenas no contexto de uma teoria que procure explicar a ligação psicológica entre votar e cooperar.

Pode-se esperar que se crie um equilíbrio diferenciador no qual os cidadãos mais cooperativos votam e os menos cooperativos deixam de votar. Nos Estados Unidos 
da América, desaprovam-se aqueles que deixam de votar e admitem isso publicamente. Tal reação é inexplicável para uma teoria que postule a existência de um gosto por votar, mas ela se segue de um modelo de sinalização: na desaprovação do receptor, podemos ver sua visão sobre o emissor, qual seja, pode ser que não se trate de uma pessoa confiável. Tempos de emergência nacional podem estimular a criação de um estado de equilíbrio agregador no qual todos (ou quase todos) votam. A principal razão para votar em uma situação como essa não é a importância do voto singular (ele continua importando pouco), mas o fato de que é importante que todos saibam que você não é um trapaceiro.

Não tenho espaço aqui para pesquisar evidências a favor e contra uma explicação do ato de votar segundo a teoria da sinalização, mesmo assim, mencionarei algumas. Primeiro, o fato de o percentual de votantes aumentar com a riqueza e a educação ${ }^{33}$ fala a favor da teoria da sinalização e contra a teoria que postula a existência de um gosto por votar. Uma ação precisa ser custosa para funcionar como um sinal: o custo de votar cresce na proporção dos custos de oportunidade. Segundo, o percentual de votantes aumenta na proporção do aumento da participação em organizações como associações de pais e mestres, de caridade, de moradores, comerciais, grupos de interesse e sindicatos. ${ }^{34}$ Todas essas associações exigem de seus membros comportamentos cooperativos. Terceiro, o freqüente exagero dos entrevistados ao falar de seu comportamento como votantes sugere embaraço em admitir que costumam não votar. Tal embaraço pode expressar a preocupação com sua reputação. ${ }^{35}$

Alguns países penalizam os não-votantes com multas de baixo valor; a Itália expõe publicamente o nome dos não-votantes. Todos esses países experimentam um alto percentual de cidadãos votantes (HASEN, 1996, p. 2160-2161). As duas formas de regular reduzem o custo do sinal, votar, mas o primeiro método confia na burocracia do Estado e o segundo, nas sanções sociais que existem independentemente das leis.

A ansiedade diante do baixo comparecimento às urnas é freqüentemente objeto de piadas, pois este fato pode significar que as pessoas estão relativamente satisfeitas com o status quo. O problema é que, no entanto, com a paz e a prosperidade, importa menos saber quem é cooperador ou trapaceiro, portanto, tende-se a deixar de votar como um sinal de patriotismo. Se o resultado disso for uma queda no percentual de votantes, haverá falta de informação sobre a preferência política dos cidadãos, o que pode levar os políticos a agir equivocadamente. Entretanto, um estado de equilíbrio em que todos votam também é indesejável. Aqueles que votam apenas para manter sua reputação não levam o ato de votar a sério e deixam de se informar sobre os vários candidatos. Votam movidos pela doçura ou pela familiaridade com os nomes dos candidatos.

\subsection{DisCRiminAÇÃo POR RAÇA, ETNIA E RELIGIÃo}

A discriminação de membros de um grupo pode servir como sinal da propensão a colaborar ou como sinal de "patriotismo". Recusar-se a lidar socialmente ou 
comercialmente com um determinado grupo é uma ação custosa, pois os membros do grupo discriminado têm determinadas habilidades e outras qualidades desejáveis. Pode emergir um equilíbrio diferenciador ou um equilíbrio agregador ativo, se os membros do grupo que pratica a discriminação reconhecem-na como um sacrifício em prol do grupo. ${ }^{36}$

Por que alguém pensaria que a discriminação de minorias é um sinal da propensão a colaborar? Por vezes, a resposta é a seguinte: o grupo discriminado tem conexões sociais ou ancestrais com determinado grupo que constitui uma ameaça inequívoca aos autores da discriminação. Exemplos incluem os norte-americanos de origem japonesa após o bombardeio de Pearl Harbor e descendentes de sérvios que vivem na Croácia ou na Bósnia. Outras vezes, a resposta é que os membros do grupo discriminado disputam recursos escassos com o outro grupo. Se a migração de negros ameaçar o domínio dos brancos sobre o mercado de trabalho, os brancos podem demonstrar sua lealdade a seu grupo discriminando os negros. Às vezes, um grupo minoritário prospera enquanto o restante da população passa dificuldades. A fonte de sua riqueza não é compreendida, mas pode estar remotamente ligada aos problemas da maioria. O domínio dos judeus sobre o mercado de crédito, e outros mercados importantes, ao longo de história da Europa, deu a eles um poder desproporcional ao tamanho do grupo. Resultado: este fato foi utilizado como justificativa para teorias que afirmavam serem os judeus uma influência danosa. Tais fenômenos reforçam uns aos outros: quando membros de um grupo discriminado se saem bem no mercado ou na sociedade, tornam-se suspeitos aos olhos dessa mesma sociedade. Seus membros (os membros da sociedade) tendem a discriminá-los para mostrar lealdade a seu próprio grupo. Da parte do grupo discriminado, tal ação faz com que seja cada vez mais importante que seus membros apóiem uns aos outros, aumentando, dessa forma, sua confiança e seus ganhos mútuos. Como resultado, temos mais discriminação por parte dos membros da sociedade. ${ }^{37}$

A discriminação de grupos por razões puramente auto-interessadas é freqüentemente objeto de racionalizações. Uma das mais comuns é a teoria que prega a superioridade racial ou étnica. Teorias assim são fornecidas incessantemente por empresários normativos. A transparente falsidade dessas teorias (não é verdade que os sérvios sejam superiores aos croatas [como crêem os sérvios], tampouco que os croatas sejam superiores aos sérvios [como crêem os croatas], que os arianos sejam superiores aos eslavos [como os nazistas acreditavam] ou que os eslavos sejam superiores a todos os demais, e assim por diante) apenas evidencia que as forças que levam as pessoas a um estado de equilíbrio na sinalização são mais fortes do que seu desejo de verdade. Da mesma maneira que alguém pode mostrar seu patriotismo em um país totalitário ao endossar propagandas evidentemente falsas (quanto mais falsa for a propaganda, mais efetivo será sinal), outros podem demonstrar seu patriotismo em países fascistas ao discriminar grupos minoritários, mesmo que 
nutram sentimentos calorosos em relação a esse grupo ou, ainda, que a minoria seja definida arbitrariamente. ${ }^{38}$ A teoria da sinalização enfatiza, portanto, a arbitrariedade das ideologias estatais, sejam elas étnicas, religiosas ou nacionalistas. O que conta como sinal depende da importância da cooperação para os indivíduos (que aumenta ou diminui com as flutuações da economia e da política), os acidentes históricos que criam associações entre certos tipos de pessoas e certos comportamentos e o custo relativo das ações que se destacam em razão dessas associações. Estas evidências contrastam claramente com a idéia de que pessoas com certas características, como etnia e raça, encontram sua posição "natural” na situação de submissão a um certo governo. A teoria da sinalização, de fato, mostra que a etnia e a raça são invenções criadas como reação a demandas por critérios que facilitem a cooperação em face de ameaças potenciais. ${ }^{39}$

O custo social desse comportamento é óbvio, no entanto, vale a pena mencionar que, neste caso, ao contrário da queima da bandeira, da autocensura e do ato de votar, o sinal fere pessoas que não participam do jogo. Os membros da minoria não são os "trapaceiros"; aqueles que se eximem de praticar atos discriminatórios é que são os "trapaceiros”. É muito provável que uma teoria que sustente a seguinte idéia: "não discriminar é sinal da presença de um trapaceiro" também conclua serem trapaceiros todos os membros do grupo discriminado. No entanto, o membro do grupo dominante que resolver tratar os excluídos com respeito será especialmente desprezado. ${ }^{40}$

É desnecessário repetir aqui a análise dos equilíbrios. Em vez disso, mencionarei brevemente os quatro tipos de lei descritos acima. Primeiro, uma lei antidiscriminatória aumenta o custo de emitir o sinal e, assim, possivelmente, reduz a quantidade de discriminação. Segundo, porque no Sul ${ }^{41}$ exigiu-se que brancos relegassem ao ostracismo brancos que trataram negros como iguais ${ }^{42}$ (em razão de uma norma social, e não de uma lei). O ganho de um receptor que resolva cooperar com um branco que cooperou com um negro será reduzido em função da expectativa de que ele seja sancionado por desrespeitar a norma social que exige dele a ação de relegar esse branco ao ostracismo. Terceiro, o uso de propaganda para convencer os cidadãos de uma ameaça interna ligada a pessoas que não pertencem à minoria (ou seja, os trapaceiros) poderia aumentar o incentivo para que as pessoas praticassem discriminação como uma maneira de evidenciar que não pertencem ao grupo dos trapaceiros. Quarto, o Estado, agindo como empresário normativo, pode tentar, desde logo, estabelecer qual é o sinal, por exemplo, endossando ou rejeitando doutrinas que pregam a superioridade racial e colocando símbolos religiosos em propriedades públicas.

A teoria da sinalização ajuda a explicar a rapidez com que as normas sobre discriminação mudam. Os judeus haviam sido assimilados à sociedade alemã décadas antes da ascensão de Hitler; poucos anos depois eles eram párias. Os negros foram párias na sociedade norte-americana séculos antes do movimento pelos direitos 
civis; no espaço de uma geração, as formas mais óbvias de discriminação desapareceram. É possível que tais mudanças se expliquem por alterações fundamentais nas atitudes, no entanto, sua rapidez somada ao sentimento disseminado, especialmente entre as minorias, de que elas foram vazias, sugerem a influência de equilíbrios de sinalização.

Devemos dizer mais sobre o papel do Estado no papel de empresário normativo. Pronunciamentos oficiais exercem um papel importante, pois as autoridades são objetos da atenção de toda a nação e, portanto, podem criar pontos focais com facilidade, por exemplo, as sedutoras teorias de Hitler sobre a influência dos judeus. O sucesso dos políticos nesse campo dá conta do conteúdo altamente simbólico de grande parte do comportamento político. Ocupantes de cargos públicos e candidatos precisam dar as mãos, marchar em paradas e comparecer a cerimônias organizadas por membros de organizações étnicas poderosas, pois, no momento em que um político for associado a um grupo minoritário, ele não terá credibilidade para, em algum momento, tentar explorar as circunstâncias e atribuir os problemas àquele grupo. No momento em que tal grupo for considerado malévolo, a ligação do político com ele afetará negativamente sua imagem.

O empresário normativo reconhece que há perigo para a ordem social quando a minoria torna-se invisível: leis que definam a minoria podem evitar que o sinal torne-se excessivamente custoso. A estrela amarela nazista e as leis antimiscigenação norte-americanas minimizaram o custo do sinal, pois eliminaram qualquer ambigüidade na identificação das pessoas que deveriam ser discriminadas. As "leis Jim Crow"43 proporcionaram aos brancos oportunidades repetidas para sinalizar com a discriminação racial. Elas abriam a possibilidade, nunca aproveitada por ninguém, de rejeitar publicamente as normas raciais. Assim, além de reforçarem a segregação, essas leis lembravam a todos que todos emitiam o sinal. De outra forma, a má memória, os ganhos potenciais advindos do ato de cooperar com as minorias e a ambigüidade dos comportamentos fariam, ao longo do tempo, diminuir a efetividade do sinal.

Diante da perda da efetividade do sinal, responsável pela identificação dos trapaceiros em razão da influência de algum desses fatores e a necessidade de identificar os trapaceiros permanecer, os empresários normativos buscarão novos sinais. ${ }^{44}$ Os exemplos mais impressionantes das mudanças de sinais resultantes de situações como essa vêm, de novo, da história do anti-semitismo europeu. Na Espanha do século XIV, na Alemanha e em toda a Europa do século XIX, a discriminação de alguém por ser judeu perdeu a efetividade como mecanismo diferenciador. Na Espanha, isso se deveu ao fato de que a perseguição levou os judeus e imigrar ou a converter-se ao catolicismo. Na Alemanha, os fundamentos teológicos da discriminação perderam sua plausibilidade diante da perda de influência geral da religião sobre a sociedade. No entanto, a demanda por unidade nacional 
em ambos os países fez nascer a necessidade de um método para distinguir pessoas leais de pessoas desleais. Tal necessidade estimulou o desenvolvimento de uma nova teoria baseada na raça, e não na religião. Todos aqueles que praticavam rituais judaicos ou cujos parentes praticavam tais rituais foram classificados como judeus raciais. Esta abordagem, ao definir o grupo de pessoas que podiam ser objeto de discriminação, procurava lidar com problemas criados por tendências demográficas e teológicas. Os empresários normativos promoveram teorias raciais para suplementar (no caso da Espanha) ou para substituir (no caso da Alemanha) as teorias religiosas. ${ }^{45}$

\section{Alguns temas}

\section{I IMPLICAÇÕES POSITIVAS ${ }^{46}$}

Como mencionamos acima, o Estado pode influenciar os estados de equilíbrio de quatro maneiras diferentes. Primeiro, uma lei, tipicamente, influencia no custo relativo do ato de emitir o sinal. Uma lei antidiscriminação aumenta o custo de emitir um sinal de patriotismo via discriminação; uma lei que institua a censura aumenta o custo de sinalizar o patriotismo pela omissão em criticar o governo. Segundo, a lei pode influenciar os ganhos resultantes da cooperação tanto para emissores quanto para receptores. Exemplo: uma lei que tribute os empregadores que contratarem críticos do governo ou pessoas que violem normas largamente aceitas, que imponham a exclusão racial. Terceiro, a lei pode alterar a crença dos receptores sobre a proporção dos tipos de cidadão em uma certa sociedade. A propaganda produz esse efeito pela persuasão: outras leis, como as que impõem a deportação ou o aprisionamento de membros do grupo "errado", mudam as crenças porque, de fato, alteram a proporção. Quarto, uma lei pode influenciar ou excluir os esforços de um empresário normativo em construir novos sinais; leis e atos oficiais criam novos sinais ou refinam sinais já existentes por proporcionarem maiores oportunidades para que sejam emitidos ou por destacá-los.

Tentar prever os efeitos de uma lei pode levar a uma série de complicações. Primeiro, o efeito de uma lei depende do estado de equilíbrio vigente. Uma lei sobre censura imposta em um estado de equilíbrio agregador ativo pode não ter efeito algum sobre o comportamento dos cidadãos; imposta sobre outros estados de equilíbrio, pode produzir algum efeito relevante. Segundo, mesmo examinando-se um determinado estado de equilíbrio em particular, é difícil prever os efeitos de uma lei. Como já visto na Secção III. A, uma lei que reduza o custo de um sinal pode produzir um equilíbrio agregador ativo, bem como um equilíbrio agregador passivo. Terceiro, uma lei específica pode influenciar o comportamento dos cidadãos de várias maneiras diferentes, além das quatro formas já mencionadas. Por exemplo, uma lei contrária à queima da bandeira pode reduzir o custo relativo de 
agitar a bandeira em geral, mas aumentá-lo no que diz respeito aos trapaceiros, por associar esse ato a uma atividade patriótica. Assim, a lei pode, ao mesmo tempo, reforçar ou compensar os efeitos de um sinal.

Dois outros complicadores são a descontinuidade e a transformação simbólica. Para compreender o problema da descontinuidade, imagine-se um equilíbrio agregador ativo em que todos discriminam os membros de uma minoria. Suponha-se que o "gosto" por discriminar esteja distribuído de maneira uniforme: muitos desejariam não discriminar, mas reprimem esse desejo para evitar o ostracismo. Promulga-se uma lei que proíbe a discriminação. Se a sanção for leve, é improvável que afete os comportamentos, pois o custo do ostracismo excederá o custo da sanção. Se a sanção for crescendo gradualmente, terá pouco efeito sobre a discriminação: enquanto a sanção social referente à reputação for maior do que a sanção legal, os comportamentos permanecerão imunes à lei, à exceção do comportamento dos cidadãos mais extremistas. No entanto, se a sanção legal alcançar certo nível, qual seja, o de suplantar a sanção social em termos de gravidade, haverá um declínio descontínuo nos atos de discriminação. Isso se explica assim: quando os cidadãos extremistas passarem a se comportar de outra forma em número suficiente e, assim, comprometerem a manutenção do equilíbrio agregador ativo, a sanção referente à reputação desaparecerá. Nessa situação, todos aqueles que desejavam cooperar com o grupo minoritário e não o faziam por medo de comprometer sua reputação abandonarão o comportamento discriminatório. ${ }^{47}$ Esse fenômeno nos ensina que uma lei dotada de uma sanção leve (ou despida de sanção, como um anúncio oficial) pode ter efeitos desproporcionais sobre o comportamento; de outro lado, uma lei dotada de sanções severas pode não ter efeito algum sobre os comportamentos. Normas sociais são robustas, mas também delicadas. ${ }^{48}$

Transformações simbólicas ocorrem quando símbolos antigos não funcionam mais em razão de fatores exógenos e, assim, deixam de ser um bom critério para distinguir os cooperadores dos trapaceiros. Conseqüentemente, os empresários normativos são estimulados a descobrir novos sinais para substituí-los. Já discutimos o processo de substituição da discriminação religiosa pela discriminação racial quando esta se tornou sinal de lealdade diante da perda de efetividade da primeira. Outro exemplo, que apresentaremos de forma estilizada, vem da era McCarthy. Aproximadamente na mesma época em que McCarthy estava ligando comunismo e subversão, outros conectavam homossexualismo e subversão. Graças ao relatório Kinsey, amplamente lido, e aos deslocamentos sociais e demográficos decorrentes da Segunda Guerra Mundial, subitamente ficou evidente que muitas pessoas adotavam práticas homossexuais, assim como muitas pessoas apoiavam os comunistas. Cooperar com homossexuais identificáveis é uma ação custosa, portanto, pode funcionar como sinal de cooperação, mas, para que tal sinal funcionasse a contento, era preciso que as pessoas acreditassem que ele era 
capaz de expressar a propensão para colaborar, e não apenas uma convicção, um preconceito ou um gosto. Os empresários normativos precisaram conectar homossexualidade e subversão, o que foi feito de várias formas, por exemplo, por meio do apelo à antipatia aos homossexuais, que deriva da tradição e da religião, ligada à afirmação da importância da unidade nacional para a segurança. Além disso, com a afirmação de que os homossexuais corrompiam a masculinidade da juventude, “masculinidade” em que a sociedade confiava para se defender (D'EMILIO, 1983). Mas, porque os homossexuais não representavam uma ameaça maior do que qualquer outra e, além disso, porque não era mais custoso para um trapaceiro discriminar os homossexuais do que para um patriota, algo como um equilíbrio agregador ativo se formou. Ataques crescentes a homossexuais, legais e não-legais, ocorreram em paralelo à maior parte dos ataques não-oficiais aos comunistas (D’EMILIO, 1983).

Uma transformação simbólica ocorre quando certo sinal (a autocensura) falha ao expor os trapaceiros em virtude, provavelmente, de mudanças exógenas nas recompensas, resultando na substituição ou adição de um novo sinal (a discriminação contra homossexuais). A ironia é que, se algum cidadão americano representava, de fato, uma ameaça na década de 1950, ele seria um comunista ou crítico de outra matriz ideológica, e não um homossexual. No entanto, a discriminação aos homossexuais permitiu a criação de um estado de equilíbrio bem mais poderoso do que a discriminação aos comunistas. Isso se deveu, provavelmente, à tradição norte-americana, anterior anosa década de 1960, que dava suporte à liberdade política e ao respeito à religião, mas não à liberdade sexual. Por isso, a autocensura constituía um sinal de patriotismo (de fato, poderia ser interpretada como falta de patriotismo) menos confiável do que a discriminação aos homossexuais.

\subsection{IMPLICAÇÕES NORMATIVAS}

Quando uma lei gera um novo equilíbrio sinalizador, avalia-se o direito comparando o novo equilíbrio com o velho. Ao fazer isso, é necessário dar conta dos efeitos comportamental e hermenêutico da lei.

\subsection{O EFEITO COMPORTAMENTAL}

É fato conhecido que não se podem hierarquizar os equilíbrios sinalizadores por sua contribuição para o bem-estar social sem informações sobre os custos e os benefícios de cada tipo de equilíbrio. À primeira vista, um equilíbrio diferenciador pode parecer superior a um equilíbrio agregador, porque no primeiro a informação é revelada e é freqüentemente considerada algo valioso. Pode acontecer de os ganhos resultantes da exposição da informação em determinado equilíbrio diferenciador serem menores que os custos de sinalizar. Também pode acontecer que um equilíbrio agregador ativo seja superior ao equilíbrio diferenciador, pois revelar a informação pode 
reduzir os incentivos para gerar valor. ${ }^{49}$ Evitei tirar conclusões sobre o ganho de bem-estar geral da conversão de um equilíbrio no outro, pois não se pode generalizar com precisão sobre os custos e benefícios de cada tipo de equilíbrio.

Ainda assim, podemos esboçar três generalizações. Primeiro: há uma tensão entre o motivo pelo qual uma pessoa age e a contribuição para o bem público. Além disso, há uma tensão entre dois tipos de bens públicos resultantes de uma ação. De um lado, a revelação da informação e, do outro, a produção de algum outro bem público. Por exemplo, uma pessoa pode votar ou praticar autocensura para sinalizar que é um cooperador ou um patriota. Votar, felizmente, produz um bem público externo (revelar preferências políticas); a autocensura produz um mal público externo (ocultar as preferências políticas). Ambos os tipos de ação produzem um bem público interno, a exposição de trapaceiros, mas, mesmo nesse caso, o custo da sinalização pode ser superior aos benefícios resultantes da informação revelada. Sinalizar não é intrinsecamente algo benéfico para a sociedade: às vezes é benéfico, às vezes não.

Segundo: sinais são grosseiros (crude) e mesmo equilíbrios que possam ser considerados benéficos pela sociedade produzem alguns comportamentos indesejáveis. Cidadãos politicamente desinformados votam para evitar sanções reputacionais. Seria mais desejável que eles seguissem suas preferências não reputacionais e deixassem de votar. Quando um equilíbrio por autocensura emerge, constitui-se a estabilidade política, o que pode ser importante em tempos de guerra, no entanto, cooperadores com críticas válidas ao governo serão silenciados com os trapaceiros.

Terceiro: quando os equilíbrios sinalizadores são benéficos, podemos esperar que eles ocorram raramente. A razão é que um sinal é um bem público (isso não é verdade para modelos sinalizadores padrão, mas eles não dão conta da ambigüidade das ações que podem servir como signos). Para que ele se estabeleça, todos devem reconhecer que certas ações são mais baratas para alguns tipos de cidadão que para outros. Mas, porque os benefícios do sinal são experimentados por todos, enquanto os custos de fazer tal conexão são suportados por alguns poucos (os empresários normativos, fofoqueiros), haverá poucos tipos de sinal disponíveis para o uso. ${ }^{50}$ Por razões similares, equilíbrios prejudiciais ocorrem com menos freqüência do que aconteceriam se não fossem produzidos por esforços coletivos.

\subsubsection{O EFEITO HermenêUtico:}

A CRIAÇÃO DO SENTIDO SOCIAL E O PROBLEMA DA REIFICAÇÃO

Quando a lei transforma um equilíbrio diferenciador em um equilíbrio agregador ativo, as pessoas param de associar o sinal com uma propensão a cooperar com o patriotismo e, ao contrário, associam o sinal com a qualidade de não ser um trapaceiro. Esse resultado pode ser indesejável quando se dá importância ao "sentido social" da ação que 
funciona como sinal. Essa é a diferença entre hastear a bandeira norte-americana em uma casa no subúrbio norte-americano e hasteá-la em um país estrangeiro hostil, ou a diferença entre criticar as autoridades em uma democracia e uma ditadura, ainda, é a diferença entre usar um triângulo rosa em um campus universitário na década de 1990 e fazê-lo na década de 1970 ou no começo da década de 1980. Porque todos ou quase todos emitem o sinal ele deixa de distinguir uma pessoa da outra. O "sentido social" de uma ação, que pode ser definido como a crença que o receptor médio tem do tipo de pessoa que se engaja naquela ação, ${ }^{51}$ tornou-se "reificado".

Quando a lei transforma um equilíbrio diferenciador em um equilíbrio agregador passivo, o sinal desaparece. Veteranos reclamam que hoje não se leva a bandeira tão a sério quanto antigamente. Naquela época, o sinal, apesar de reificado, não era algo sem sentido: poucas pessoas deixavam de saudar a bandeira, mas aqueles que o faziam eram necessariamente trapaceiros. Assim, todos aqueles que saudavam a bandeira eram, ao menos, cooperadores em potencial. Hoje, saudar a bandeira é algo praticamente sem sentido em vários círculos. Um observador pressupõe que aquele que saúda a bandeira é antiquado ou mesmo um pouco amalucado, uma pessoa com gostos estranhos. Quando um observador não é mais capaz de associar um sinal a um determinado tipo de cidadão, pois muito poucos o emitem, pode-se dizer que o sinal foi "destruído".

Quando o Estado converte um equilíbrio agregador passivo em um equilíbrio diferenciador, produz sentido social. Uma ação que antes tinha pouco significado agora tem muito. Saudar um pedaço de tecido estampado com estrelas e listras não tinha importância nenhuma antes da guerra revolucionária; mais tarde significaria muito. A discriminação de homossexuais é vista inicialmente como uma reação a práticas consideradas imorais. Após a ação estatal, a discriminação é considerada uma expressão de patriotismo. Assim, um sentido social é criado. ${ }^{52}$

A despeito de toda a ênfase que demos ao papel do Estado, um sentido social pode surgir e desaparecer espontaneamente muitas vezes, apesar do esforço estatal de regulá-lo. Para entender o porquê, suponha que, em um momento 1 , há um equilíbrio diferenciador e os cooperadores saúdam a bandeira apenas para mostrar que são cooperadores. No momento 2, o Estado promulga uma lei que pune as pessoas que deixam de saudar a bandeira. No momento 3 , há um equilíbrio agregador ativo criado pelo desejo dos trapaceiros de se esquivarem da punição, mas neste momento, saudar a bandeira não é mais um sinal confiável de patriotismo. Se muitas pessoas saúdam a bandeira apenas para evitar a sanção, aqueles que o fazem não são necessariamente cooperadores: a saudação se reifica. No jogo do patriotismo, ambos os tipos de cidadão continuam a saudar a bandeira, os cooperadores, por temerem ser tomados por trapaceiros, caso deixem de fazê-lo. Mas, ao longo do tempo, muitas pessoas, cooperadores ou não, começarão a reconhecer o ato de saudar a bandeira como o ritual vazio que ele se tornou. Saudar a bandeira se torna algo embaraçoso, pois 
todos sabem que se saúda a bandeira apenas para evitar a punição legal. Alguns esconderão seu embaraço atrás de uma máscara de ironia, mas, sob tais condições, os sentidos da saudação podem eventualmente "virar", tornando-se um sinal do medo da punição legal, e não de patriotismo. ${ }^{53} \mathrm{~A}$ pessoa que saúda é abjetamente obediente e temerosa de ofender a autoridade alheia. A pessoa que deixa de saudar é íntegra e independente e tem uma natureza cooperativa autêntica. Deixar de saudar a bandeira torna-se um sinal de patriotismo melhor do que saudá-la. E acredito que seja assim em alguns círculos.

A "politização" do comportamento ocorre com a criação de uma lei que exija que as pessoas se engajem em comportamentos nos quais já haviam se engajado voluntariamente. As pessoas saúdam a bandeira ou rezam em cerimônias, então, uma lei é criada para exigir exatamente o mesmo comportamento. À primeira vista, poder-seia esperar que a lei não afetasse o comportamento ou que talvez o intensificasse, mas a lei pode "virar" o sinal de tal forma que o emissor passe a temer que os outros pensem que ele adota esse comportamento para cumprir a lei em vez de expressar genuíno patriotismo ou fervor religioso. O resultado pode ser que as pessoas parem de adotar o comportamento ou não, o que dependerá da intensidade das sanções e de outros parâmetros. A conclusão importante para nossos objetivos é que a politização destrói sentidos sociais importantes ao exigir, por meio de lei, comportamentos cujo sentido deriva, em parte, do fato de não serem exigidos por lei. Esse argumento é uma analogia ao argumento segundo o qual a "comodificação" de bens e serviços pelo mercado destrói o sentido social nos casos em que um comportamento deriva seu sentido do fato de que é oferecido gratuitamente. ${ }^{54}$

\subsection{Endogenização do Estado}

Vários artigos recentes afirmam que o Estado tem um papel importante em administrar normas e sentidos sociais. Normas, sentidos sociais e fenômenos similares criam externalidades que não podem ser barganhadas. Pode-se esperar que o mercado não forneça as normas e os sentidos sociais desejáveis, portanto, o Estado deve fazê-lo ou encorajar seu fornecimento por meio de incentivos legais (Lessig (1995); Sunstein (1996); Pildes (1991)).

Há problemas nesse argumento. Suponhamos que todos pratiquem a autocensura para evitar serem taxados de trapaceiros. O equilíbrio agregador ativo não está a serviço do interesse da maior parte do povo, no entanto, cada um dos cidadãos teme desviar-se dele. Pode-se dizer que, nesse caso, há um problema de ação coletiva que o governo poderia resolver, por exemplo, subsidiando a publicação de jornais e revistas, concedendo a políticos horário gratuito na TV, promulgando leis que imunizassem os cidadãos contra acusações de injúria e difamação e garantindo outros privilégios e subsídios. O problema é saber por que devemos supor que o governo tomaria qualquer uma dessas medidas. Não se trata apenas de sabermos que os funcionários do 
governo poderiam apreciar a ausência de crítica na sociedade. A questão é: tais funcionários não irão propor leis como essas para evitar que seu apoio seja interpretado como um sinal da presença de um trapaceiro. Os cidadãos não farão pressão sobre o governo para promulgar tais leis, pois tal pressão, que viola a regra da autocensura, também será tomada como sinal da presença de trapaceiros. Não se pode esperar que o governo mude sentidos sociais indesejados quando eles são suficientemente fortes.

Tais considerações nos remetem à questão que levantamos no começo deste artigo: por que as pessoas buscam obter a promulgação de leis contra a queima da bandeira, se tal ato não causa nenhum dano "real"? Uma resposta possível é seguinte: os cidadãos sinalizam seu patriotismo não apenas com ações patrióticas, mas também fazendo pressão ou, ao menos passivamente, demonstrando apoio a leis que punam atividades não-patrióticas. A segunda resposta segue-se logicamente da primeira. Se o sinal, apoio político, for suficientemente barato, pode-se constituir um equilíbrio agregador ativo. Ainda, se o apoio a uma lei contra a queima da bandeira for tomado como sinal de patriotismo, funcionários eleitos do governo não poderão suportar as conseqüências políticas de se oporem a tal lei, tampouco professores de direito que esperem ser indicados a posições importantes no governo. ${ }^{55}$

Quando o governo age como empresário normativo, produz uma competição desnecessária por recursos governamentais. Grupos que competem entre si tratam o governo como um instrumento para transmitir seus símbolos. Um exemplo importante é a exposição de símbolos religiosos em prédios públicos. Um observador que veja tais símbolos interpretará tal fato como resultado da pressão de um grupo religioso e, portanto, concluirá que esse grupo tem uma influência política significativa. Tal inferência faz com que os receptores acreditem que o grupo religioso possui muitos membros ou muito poder. Em ambos os casos, os membros do grupo tendem a ser considerados parceiros desejáveis (ou inevitáveis) para ações de cooperação. Por isso, serão vãs as tentativas dos membros da maioria de discriminá-los para emitir um sinal de lealdade ou patriotismo. É do interesse dos grupos religiosos competir pela influência sobre a decisão governamental de utilizar ou não de símbolos religiosos. Restrições constitucionais impedem uma competição dispensável entre os grupos religiosos que disputam o governo como instrumento para recrutar novos membros como forma de apoio a suas crenças. ${ }^{56} \mathrm{~A}$ liberdade religiosa e as leis que estabelecem o dever do Estado de tratar todos como iguais protegem, até certo ponto, os membros de minorias religiosas contra esse tipo de discriminação, que estimularia a disputa pelo poder político.

\section{CONClUSÃo: Símbolos E NORMAS SOCIAIS}

Para compreender o que são as normas sociais é preciso utilizar modelos diferentes conforme o contexto, ${ }^{57}$ pois a expressão "norma social" é usada na linguagem comum 
para se referir a muitas espécies de comportamento. Neste artigo, afirmei que uma classe importante de normas sociais emerge de jogos de sinalização nos quais as pessoas escolhem as ações que sinalizam lealdade a Estados e comunidades. Porque as pessoas adotam um comportamento em particular apenas para mostrar que são leais, este comportamento adquire a qualidade peculiar de ser um símbolo vazio. As pessoas não sentem prazer algum (ou sentem pouco prazer) em comportar-se daquela maneira, mas o fazem em nome de sua reputação. Note-se que a norma social é endógena ao modelo: ela descreve o comportamento que resulta no equilíbrio. Não é que $\mathrm{X}$ puna $Y$ por violar a norma social, ao contrário, $\mathrm{X}$ (e muitos outros) evita $\mathrm{Y}$ porque $\mathrm{o}$ comportamento de $\mathrm{Y}$ revela a $\mathrm{X}$ que, se associar a $\mathrm{Y}$ não servirá aos interesses de $\mathrm{X}$. Embora na linguagem usual digamos que o comportamento de $\mathrm{Y}$ viola uma norma social, a punição é endógena, não é imposta por uma força externa. ${ }^{58}$

Este artigo contribui para a literatura sobre o direito e as normas sociais de três formas. Primeiro, ele incorpora o comportamento simbólico na análise geral. Segundo, mostra como um modelo de sinalização pode iluminar a relação entre o direito e as normas sociais. A principal alternativa, o modelo do jogo de repetição, explica como a cooperação é possível, mas não explica como surgem comportamentos padronizados ou influenciados por normas. A maior parte das discussões sobre normas sociais na literatura jurídica diferencia-se de duas maneiras: fazendo suposições exógenas sobre a razão pela qual as pessoas cooperam e tornando as preferências endógenas. ${ }^{59}$ Por razões que devo explicitar, afirmo que este modo de ver o problema é um retrocesso. Pode-se fazer muito progresso em explicar a relação entre direito e comportamento sem recorrer a argumentos sobre preferências, notoriamente difíceis de analisar. Terceiro, este artigo revela como as normas sociais podem ser patológicas ou ineficientes. ${ }^{60}$

O último ponto que levantamos sugere, é claro, a possibilidade de uma intervenção estatal desejável. No entanto, há também várias razões para manter o ceticismo diante de propostas que envolvam o Estado em esforços conscientes de "regular" o sentido social. Primeiro, os funcionários do governo não se colocam fora do jogo de sinalização. Como cidadãos, eles são prisioneiros dos símbolos, se eles forem suficientemente fortes. Truman e Eisenhauer foram impotentes para resistir a McCarthy em seu auge, pois qualquer esforço para criticá-lo seria interpretado como um sinal da pusilanimidade do presidente, ou mesmo sua simpatia pelos inimigos dos Estados Unidos da América. Segundo, o efeito dos esforços governamentais para alterar um sinal pode ser oposto ao desejado, resultando no fortalecimento do símbolo que o governo desejava mudar (um possível exemplo são os esforços de Clinton em aumentar a aceitação dos gays entre os militares) ou na reificação do símbolo visado (um efeito possível de uma lei que banir o desrespeito à bandeira). Quando os esforços governamentais, deliberadamente ou não, destroem ou reificam os símbolos existentes, empresários normativos proporão novos símbolos, que podem ter efeitos piores 
do que os anteriores. Quem procurar exemplos de esforços governamentais bemsucedidos na exploração do comportamento simbólico encontrará repetidamente, na história de Estados fascistas e totalitários, modelos nada atrativos para os Estados Unidos, país em que as ações de empresários normativos que alcançaram maior sucesso foram realizadas por movimentos não-governamentais, como o movimento pelos direitos humanos, o feminismo e o evangelismo religioso.

\section{NOTAS}

1 Professor de Direito Assistente na Universidade da Pensilvânia (*NT: atualmente professor na Universidade de Chicago). Agradecimentos do autor a Matthew Adler, Douglas Baird, Steve Coate, Jason Johnston, Timur Kuran, Richard McAdams, Geoffrey Miller, Eric Rasmusen e participantes nessa Conferência e debates no Encontro Anual da American Law and Economics Association, Toronto, 1997. Karen Schoen contribuiu com valiosa assistência de pesquisa.

2 NT: A disciplina de Direito e Economia, da qual Eric Posner é um expoente, considera que mudanças legislativas alteram incentivos e, desta forma, controlam o comportamento dos indivíduos impondo "preços" elevados a condutas indesejadas. Por exemplo, aumentos nas multas por excesso de velocidade supostamente fazem com que motoristas dirijam de forma mais cautelosa. Embora essa visão centralizadora (e positivista) predomine, recentemente, adeptos da disciplina têm buscado compreender também como hábitos e costumes influenciam e regulam condutas: a indução de comportamentos vistos como desejáveis pode ser alcançada pela alteração das chamadas "normas sociais". O estudo das normas sociais relativiza, mas também aperfeiçoa, os modelos de escolha racional (rational choice) comumente empregados nos estudos de Direito e Economia.

3 NT: Isto é, centrais e relevantes.

4 NT: Na presença de relevantes assimetrias de informação, os indivíduos se vêem obrigados a tentar adivinhar os reais interesses das outras partes. Por exemplo, em uma negociação para compra e venda de um carro usado, o vendedor conhece muito melhor o verdadeiro estado de conservação do carro. Dependendo de como o vendedor se comportar vale dizer, dos sinais emitidos por ele - o comprador ofertará um valor maior ou menor pelo carro. O chamado equilíbrio diferenciador (separating equilibrium) surge quando a parte menos informada consegue deduzir os reais interesses da parte mais bem informada, com base nos sinais por ela emitidos. Por exemplo, o comprador pode deduzir que se trata de um carro em bom estado de conservação porque o vendedor provou que todas as revisões foram feitas, que a quilometragem do carro é baixa para seu ano de fabricação e que o estepe nunca foi usado.

5 NT: O termo "equilíbrio" designa situações em que forças antagônicas encontram-se balanceadas e estáveis, de forma que, na ausência de influências externas, a situação não se alterará. O exemplo mais evidente é o equilíbrio de mercado, que ocorre quando o preço de um determinado bem, estabelecido em regime de competição em mercado, é gerado no momento em que a quantidade de bens produzidos se iguala à quantidade de bens consumidos. Há, contudo, exemplos mais sutis, e é neles que Eric Posner está interessado. A publicação da constituição de um país reflete uma situação de equilíbrio em que as diversas forças políticas, após um processo de barganha, chegam a um denominador comum; a criação da moralidade pública, do mesmo modo, emerge do choque entre as diversas visões do que seja justo, moral, útil e conveniente.

6 NT: A expressão hate speech (discurso do ódio) é muito utilizada no mundo anglo-saxão, especialmente nos EUA. Refere-se aos discursos que visam a degradar, discriminar ou incitar o ódio em relação a grupos sociais ou étnicos. O tema 
tem sido discutido entre juristas, filósofos e estudiosos de outras ciências sociais. Nos EUA, há vários diplomas legais que regulam a questão e, recentemente, a Suprema Corte tratou do assunto em R.A.V. v. City of St. Paul (1992), utilizando-se do conceito de fighting words construído em Chaplinsky vs. New Hampshire (1942). Para uma visão jurídica do problema, v. John B. Gould (Speak no evil: the triumph of hate speech regulation, Chicago: Chicago University Press, 2005). Para uma discussão filosófica, que problematiza o papel da Suprema Corte na regulação do problema, v. Judith Butler (Burning acts, injurious speech. In: Excitable speech: a politics of the performative. London: Routledge, 1997).

7 NT: Em Budapeste, por exemplo, imediatamente após a queda do regime totalitário, diversas estátuas de líderes do regime foram retiradas do centro da capital. As obras não foram destruídas, mas deslocadas para um parque (Szoborpark) na periferia da cidade.

8 NT: Como o atual desapego dos casais pelo uso da aliança como símbolo do matrimônio. Nesse caso, o abandono do símbolo proporciona uma reserva financeira ao casal (a economia do preço de um par de alianças em ouro), que pode ser usufruída por eles em outra ocasião (viagens, passeios, lazer, etc.). Assim, a desvalorização do símbolo pode ser revertida para a cooperação dos indivíduos. O desapego à utilização da aliança pode ser um sinal de que o casamento não é considerado sagrado pelos nubentes. Esse comportamento poderá sinalizar uma série de características sobre o casal. Um casal que não usa aliança provavelmente não freqüentará a igreja; possivelmente será a favor da legalização do aborto e do casamento de homossexuais; e assim por diante. É neste sentido que se diz que a não-utilização da aliança pode ser um "sinal” importante.

9 NT: A teoria dos jogos estuda situações estratégicas, nas quais os indivíduos escolhem diferentes ações na tentativa de maximizar seus benefícios aos menores custos possíveis. É comum utilizar a teoria dos jogos para modelar (i.e., tentar prever) o comportamento de indivíduos interagindo uns com os outros, pois ela se presta a analisar relações dinâmicas: se eu fizer A, como reagirão as outras pessoas? E se eu fizer B? Geralmente, o "jogo" se desenvolve em um ambiente em que cada "jogador" tem informações incompletas sobre as reações dos outros jogadores. Daí a importância dos "sinais" emitidos por cada um deles. Esse tipo de estudo tem apresentado resultados interessantes em pesquisas em diversas áreas, especialmente Economia, Ciência Política, Ética, Filosofia, Direito e Ciência da Computação. Jogos "cooperativos" são aqueles em que é possível cooperar celebrando acordos que maximizam o bem-estar do grupo porque há uma "coalizão" de jogadores capaz de fazer cumprir os acordos. Crianças jogando cobra-cega geralmente participam de um jogo cooperativo porque aquele que trapacear será expulso do jogo pelos demais ("com você eu não brinco mais"). Da mesma forma, se o Poder Judiciário for suficientemente organizado e honesto, os indivíduos podem celebrar contratos - portanto, cooperar - porque, se uma das partes romper o acordo, será processada e pagará suas obrigações prontamente com juros e correção. Os jogos "cooperativos" se opõem aos "não-cooperativos", aqueles em que a estratégia racionalmente adotada pelas partes será a de não cooperar. Por exemplo: se a lei não funciona na prática, e os mecanismos de reputacionais/sociais não são suficientemente fortes para fazer com que as regras sejam cumpridas, poderá tornar-se racional roubar, trapacear, não cumprir com a palavra dada, etc.

10 NT: O jogo é descrito da seguinte forma: dois suspeitos (A e B) são presos pela polícia após um roubo. A promotoria não tem provas suficientes para condená-los por roubo. Pode apenas condená-los por uma infração menor em que ambos receberão pena de seis meses de prisão. Para condenar A por roubo, é preciso que B confesse que realizou o roubo com A. Da mesma forma, para poder condenar B por roubo, é preciso que A confesse que realizou o roubo junto com B. A promotoria oferece, separadamente, um acordo para cada um dos dois prisioneiros: "se você confessar (e o seu comparsa mantiver-se em silêncio), você sairá livre e o comparsa receberá pena de dez anos de prisão; mas, se ambos confessarem, ambos receberão dois anos de prisão". A partir desse momento, os prisioneiros não se comunicam, isto é, decidem separadamente. O dilema de cada prisioneiro é decidir entre confessar ou calar-se. Se ambos se calam, ambos recebem pena de seis meses de prisão; se ambos confessam, os dois recebem dois anos de pena; e se um confessa e o outro não, o dedo-duro sairá livre e aquele que se manteve calado receberá dez anos de prisão. A solução clássica do dilema é que, agindo racionalmente, cada prisioneiro optará por confessar. Este jogo mostra fundamentalmente que: (i) a ação racional não é pressuposto da maximização de bem-estar; (ii) a cooperação (geralmente) é pressuposto da maximização de bem-estar; e (iii) a cooperação se instrumentaliza por meio da possibilidade da realização de acordos e contratos. Se os prisioneiros pudessem celebrar um acordo, combinariam que não iriam confessar e cada um deles receberia seis meses de pena de prisão. Como não podem contratar, ambos confessam. Em vez de ficarem seis meses na prisão, ficam dois anos.

11 NT: Como condição preliminar ao contrato, o comprador deve avaliar se o vendedor age de boa-fé, é um bom pagador: retirar as certidões para verificar a existência de pendências judiciais, fiscais e contábeis, etc.

12 Esse modelo assemelha-se aos modelos publicitários. 
13 NT: As diferenças entre as taxas de desconto entre os jogadores decorrem das preferências por recompensas de longo prazo pelos cooperadores em oposição às preferências dos trapaceiros por ganhos imediatos. Assim, para Eric Posner (Altruism, status, and trust in the law of gifts and gratuitous promises, Wisconsin Law Review. p. 579-580, 1997), o ato de entregar presentes não está limitado a uma demonstração de generosidade ou altruísmo, podendo servir também para identificar os cooperadores e os trapaceiros.

14 NT: A contribuição do equilíbrio de Nash (equilíbrio estratégico) para a teoria dos jogos foi demonstrar a existência de uma situação em que o jogador adota a melhor jogada para si em vista das jogadas de seu opositor. Trata-se de um equilíbrio de estratégias dominantes, uma vez que haverá sempre uma cooperação eficiente entre as partes. $\mathrm{O}$ equilíbrio de Nash, segundo Jean Tirole e Drew Fundenberg (Game theory. Massachusetts:The MIT Press, 2000) “é um conjunto de ações dos agentes tais que nenhum jogador, tomando as ações de seus oponentes como dadas, desejaria alterar as suas próprias ações”. Em uma das releituras dessa teoria, foram introduzidos por Harsany em 1967 os jogos bayesianos; situações em que os jogadores não conhecem a estrutura do jogo, isto é, mesmo com as repetidas jogadas não é possível determinar a estratégia dominante. Diante disso, o equilíbrio bayesiano perfeito serve como a criação artificial do equilíbrio [de Nash], ou melhor, considerando que as jogadas são dependentes de circunstâncias pouco prováveis, por exemplo, quando os jogadores não tomam as jogadas estratégicas se pudessem escolher outras, há introdução de um modelo bayesiano perfeito quando as variantes são desconsideradas e todos os jogadores escolhem as jogadas estratégicas.

15 As complicações surgem da dificuldade de consolidar conceitos satisfatórios de equilíbrio. Como exemplo, pode-se argumentar que o agrupamento ativo não é plausível. O cooperador prefere desviar do comportamento adotado se o receptor decidir cooperar com aqueles que prefiram desviar. Com isso, o cooperador irá economizar o custo do sinal (recebendo $\$ 6$ em vez de \$3). De fato, o receptor deverá acreditar que ninguém que opte por desviar o comportamento terá $90 \%$ de probabilidade de ser um cooperador, porque o cooperador e o trapaceiro agem melhor ao desviar do que ao sinalizar. Assim, admitindo que o receptor irá realmente cooperar com alguém que opte desviar do comportamento adotado, e por saber que os dois desviam melhor do que sinalizam, o receptor não terá razões para acreditar que apenas um trapaceiro optará por desviar o comportamento. Se o receptor tiver acreditado que alguém que desvie tem $90 \%$ de probabilidade de ser cooperador, ele irá cooperar. Nesse caso, portanto, o cooperador irá, antecipando tudo isso, desviar. Para uma discussão sobre a mais refinada noção de equilíbrio utilizada aqui, veja Baird; Gertner; Picker (1994, p. 255). Se o custo de um desvio sem sucesso é alto o suficiente, no entanto o cooperador irá achar inaceitável o risco de que o receptor possa equivocadamente rejeitá-lo.

16 NT: A expressão “empresário normativo” (norm entrepreneur), cunhada por Cass R. Sunstein, designa aqueles indivíduos interessados em liderar processos de mudança das normas sociais. Segundo Sunstein, "as [instituições] sociais são geralmente mais frágeis do que se poderia supor porque elas dependem das normas sociais com relação as quais - e este é um ponto fundamental - as pessoas às vezes não têm tanta fidelidade quanto se imagina [...] Os empresários normativos podem explorar este fato". (Social roles and social norms. Columbia Law Review, Vol. 96, No. 4 (May, 1996), pp. 903-968).

17 NT: Para alguns Estados norte-americanos, o dia 19 de abril é um feriado, denominado Dia da Pátria. Historicamente, considera-se, nessa data, o início da Guerra da Independência dos Estados Unidos da América em 1775. Adicionalmente, o dia 11 de setembro, por meio de decretos presidenciais renovados anualmente e, posteriormente, aprovado pelo Congresso em 2005, tornou-se o Dia da Pátria dos Estados Unidos da América, em homenagem às vítimas do atentado terrorista em Nova Iorque em 2001.

18 NT: Espírito do tempo.

19 NT: Referência ao empresário normativo.

20 NT: Referência a Joseph R. McCarthy (1908 - 1957), ex-senador norte-americano entre 1947 e 1957. A partir do início da década de 1950, McCarthy tornou-se o arauto do sentimento anticomunista nos Estados Unidos, no contexto das crescentes tensões entre aquele país e a União Soviética por conta da Guerra Fria. McCarthy notabilizou-se por realizar uma série de acusações sem provas e liderar perseguições políticas contra supostos espiões soviéticos nos Estados Unidos. A partir de 1954, suas bravatas o levaram ao descrédito e censura pública pelo Senado norte-americano.

21 Uma breve análise sobre a época de McCarthy encontra-se em Reeves (1989).

22 Ver, e.g., Pesendorfer (1995); Camerer (1988). 
23 Uma confusão adicional resulta de que em uma comunidade as pessoas demonstram lealdade pela realização de ações que violem as normas dominantes. Assim, uma pessoa pode queimar uma bandeira para mostrar aos opositores do governo que é profundamente comprometido e pode ser visto como um aliado valioso.

24 Ver Lohmann (1994, p. 518); Rasmusen (1993, p. 899).

25 Glazer e Konrad (1995, p. 167) argumentam que as firmas fazem lobby por regras protecionistas como forma de sinalizar aos entrantes em potencial que elas possuem baixos custos marginais, portanto buscam dissuadir a entrada do concorrente.

26 Ver Bernheim (1994, p. 841). Esse autor, entretanto, considera a preocupação sobre a reputação como exógena, mesmo que seja derivada dos ganhos com a cooperação.

\section{Ver Seção 4.1}

28 Para uma análise diferente sobre formas de profanar a bandeira, ver Eric Rasmusen (1998).

29 Ver Timur Kuran (1995).

30 Quando a sociedade em questão não é uma nação, mas sim uma comunidade menor, tal como uma universidade ou uma cidade pequena, obtém-se um resultado semelhante. Ver, por exemplo, Glenn C. Loury (1994).

31 Ver Donald P. Green; Ian Shapiro (1994).

32 Ver, e.g., Richard L. Hasen (1996).

33 Ver Leighley; Nagler (1992); Durden (1987).

34 Ver Stephen Knack (1992). No conjunto de 41\% dos votantes regulares, acordaram sobre o seguinte argumento para votar: "Meus amigos e familiares quase sempre votam e eu não me sinto confortável em dizer a eles que não votei" (KNACK, 1992, p. 137).

35 Presser; Traugott (1992); ver também Hasen (1996, p. 2160-2161).

36 A teoria não assume um "gosto pela discriminação" (BECKER, 1973) ou que as características físicas sejam utilizadas como equivalentes (proxy) às características não visíveis (ARROW, 1973).

37 Ver Eric A. Posner (1996).

38 Comparar McAdams (1995). O autor baseia-se na suposição de que as pessoas desejem status, isto é, derivam disso a utilidade de ser mais rico do que outra pessoa. A teoria dos sinais não faz essa suposição, aliás, pelo contrário, baseia-se nas suposições mais comuns sobre as preferências. O status, nesse modelo, é endógeno: ou seja, um possui status se o outro tem reputação para ser um parceiro de cooperação respeitável.

39 A teoria está, portanto, de acordo com a opinião de que as nações são "comunidades imaginárias", ver Anderson (1983) e a historiografia que enfatiza a contingência do Estado-nação, e.g., Hobsbawm (1990).

40 Ver McAdams (1995, 1039-1040); Kuran (1997).

41 NT: Referência aos Estados do Sul dos Estados Unidos, favoráveis à manutenção da escravatura até a Guerra Civil americana (1861-1865).

42 Ver McAdams (1995).

43 NT: As chamadas "leis Jim Crow" (Jim Crow Laws) estiveram em vigor, no período de 1876 a 1965, em cidades e Estados do Sul dos Estados Unidos. Determinavam um regime de "separação igualitária" (separate but equal) entre brancos e negros: havia escolas públicas, locais públicos e transportes públicos separados para indivíduos brancos e 
negros. Embora teoricamente devessem ser de mesma qualidade, na prática, esse regime de separação servia para criar um sistema racista e discriminatório.

44 A politização das raças realizada pelos empresários (políticos) normativos é discutida em Roback (1989).

45 Ver B. Netanyahu (1995). Netanyahu ressalta que maioria da população espanhola tinha grande interesse em adquirir o poder econômico e político dos judeus (na Espanha, os “cristãos novos", isto é, os judeus convertidos), do que se importava para cooperar em nível nacional. Por fim, o autor identifica no interesse por uma unidade nacional na Espanha como uma importante causa de perseguição dos cristãos novos. Idem, p. 1004. Portanto, a Espanha se uniu na oposição aos judeus. Mas, quando a religião judaica desapareceu, o povo judeu precisou ser recriado.

46 NT: No texto, a expressão "implicações positivas" tem o sentido de análise descritiva (como as coisas "são") e é usada em oposição à noção de "implicações normativas", proposições de como as coisas "deveriam ser". Por exemplo: uma estatística descrevendo o aumento da criminalidade é uma descrição (ou tentativa de descrição) da realidade; uma proposta de aumento das penas de prisão seria uma possível implicação normativa.

47 Cf. Bernheim (1994); Kuran (1995).

48 Ver Sunstein (1996, p. 909).

49 Ver, por exemplo, Mas-Colell et al. (1995, p. 455-457).

50 Ver Lawrence Lessig (1995).

51 Cf. Lawrence Lessig (1995).

52 A criação de sentidos sociais mediante um comportamento espontâneo pela população, porém, guiado e explorado pelos empresários normativos, colabora na explicação do fenômeno das "tradições inventadas". A conotação paradoxal deriva de que antigos comportamentos revelam pontos focais empregados para sinalizar a devoção a uma nova entidade política. Por não ser costume de nenhuma nação, exceto a Escócia, vestir o Kilt, considera-se que usar o Kilt é exclusividade do povo escocês. Entretanto, o Kilt apenas tornou-se um símbolo para o nacionalismo escocês após transformações nas condições sociais que possibilitaram a criação da comunidade escocesa. Assim, com o estabelecimento da comunidade, puderam-se obter ganhos de cooperação. Dessa forma, os empresários normativos refinaram o sinal ao, por exemplo, elaborar (como uma absoluta ficção) uma conexão entre os tartãs (tecido escocês xadrez) e os clãs. Ver Hobsbawn; Ranger (1983), especialmente o capítulo de Trevor-Roper nas tradições escocesas.

\section{Cf. Kuran (1995).}

54 Comparar Radin (1987).

55 Essas observações podem ser utilizadas para fundar uma teoria da ideologia mais abrangente, que deverá estabelecer as condições sobre as quais as pessoas aprovam (ainda que em grandes números) as posições políticas contrárias aos seus interesses. A origem dessa teoria está em Kuran (1995) e Loury (1994). Ver também Kuran (1987). Todo esse material, no entanto, serve para uma investigação futura.

56 Para uma discussão geral, ver Eric A. Posner (1996). Objeções a determinadas condutas "expressivas" de um governo derivam dos medos básicos de que tal conduta altere as crenças dos indivíduos. Em razão delas, espera-se uma redução nas habilidades dos indivíduos de relacionarem-se corporativamente. Opor-se a regras legais de um grupo em particular, mesmo que essas regras não causem prejuízos diretos ao indivíduo, justifica-se pela possibilidade de que tais regras em particular possam alterar as atitudes dos indivíduos que podem prejudicá-lo. Na minha opinião, esse tipo de motivação encontra-se também em objeções às manipulações raciais para influenciar votações (gerrymandering), não apenas em objeções morais em geral ao "reducionismo de valores" (value reductionism). A despeito disso, tais teorias são consistentes. Ver Pildes; Niemi (1993).

57 Para uma discussão de outros modelos possíveis, ver Eric A. Posner (1998).

58 Neste trabalho, afasta-se o aspecto secundário do dilema dos prisioneiros (ELSTER, 1989, p.132-133). Essa análise resulta na teoria, rejeitada neste artigo, de que as normas sociais são impulsionadas por uma ação coletiva intencional. 
59 E.g., Sunstein (1996); Lessig (1995). Ver também Robert D. Cooter (1994) e Cooter (Cornell Law Review), que combina uma teoria evolucionista do comportamento e a teoria de internalização das normas. Uma outra análise sobre as normas sociais decorre da suposição de que as pessoas desejam status para o seu próprio bem. Ver McAdams (1997); ver também Bernheim (1994).

60 Cf. Posner (1996c); Posner (1998); ver também Ellickson (1991).

\section{REFERÊNCIAS BIBLIOGRÁFICAS}

ANDERSON, Benedict Richard O' Gorman. Imagined communities: reflections on the origin and spread of nationalism. London: Verso, 1983.

ARROW, Kenneth J. The theory of discrimination. In: ASHENFELTER, Orley; REES, Albert (Ed.). Discrimination in labor markets. Princeton: Princeton University Press, 1973.

BAGWELL, Laurie Simon; BERNHEIM, B. Douglas. Veblen effects in a theory of conspicuous consumption. The American Economic Review, vol. 86, n. 3, 1996, p. 349-373.

BAIRD; Douglas G.; GERTNER, Robert H.; PICKER; Randal C.. Game theory and the law. Cambridge: Harvard University Press, 1994, p. 255.

BECKER, Gary Stanley. The economics of discrimination. 2. ed. Chicago: University of Chicago Press, 1973.

BERNHEIM, B. Douglas. A theory of conformity. The Journal of Political Economy, vol. 102, n. 5, 1994, p. 841-877.

CAMERER, Colin. Gifts as economic signals and social symbols. The American Journal of Sociology, vol. 94, 1988, pp. S180-S214.

COOTER, Robert D. Structural adjudication and the new law merchant: a model of descentralized law.

International Review of Law and Economics, vol. 14, n. 2, 1994, p. 215-231.

D’EMILIO, John. Sexual communities: the making of a homosexual minority in the United States, 1940-1970.

Chicago: University of Chicago Press, 1983.

DURDEN, Garey C.; GAYNOR, Patricia. The rational behavior theory of voting participation: evidence from 1970 and 1982 elections. Public Choice, vol. 53, n. 3, 1987, p. 231-242.

ELLICKSON, Robert. Order without law: how neighbors settle disputes. Cambridge: Harvard University Press, 1991. ELSTER, Jon. The cement of society: a study of social order. Cambridge: Cambridge University Press, 1989.

GLAZER, Amihai; KONRAD, Kai A.. Strategic lobbying by potential industry entrants. Economics \& Politics, vol. 7, n. 2, 1995, p. 167-179.

GREEN, Donald P.; SHAPIRO; Ian. Pathologies of rational choice theory: critique of applications in political science. Yale: Yale Univeristy Press, 1994.

HASEN, Richard L. Voting without law?. University of Pennsylvania Law Review, vol. 144, n. 5, 1996, p. 2135-2179. HOBSBAWM, Eric J. Nations and nationalism since 1780. Cambridge; Nova Iorque: Cambridge University Press, 1990. Press, 1983.

; RANGER, Terence O. (Ed.). The invention of tradition. Cambridge; Nova Iorque: Cambridge University

KLEIN, Benjamin; LEFFLER, Keith B. The role of market forces in assuring contractual performance. The Journal of Political Economy, vol. 89, n. 4, 1981, p. 615-641.

KNACK, Stephen. Civic norms, social sanctions and voter turnout. Rationality and Society, vol. 4, n. 2, 1992, p.

133-156.

KRISTOF, Nicholas D. Japan's state symbols: now you see them... The New York Times. 12 nov. 1995.

KURAN, Timur. Preference falsification, policy continuity and collective conservatism. The Economic Journal, vol. 97, n. 387, 1987, p. 642-665.

Private truths, public lies: the social consequences of preference falsification. Cambridge: Harvard

University Press, 1995.

From melting pot to salad bowl: ethnic activity and socially induced ethnification (paper apresentado na Chicago Social Norms Conference), 1997.

LEIGHLEY, Jan E.; NAGLER, Jonathan. Individual and systematic influences on turnout: who votes?. The Journal of Politics, vol. 54, n. 3, 1992, p. 718-740.

LESSIG, Lawrence. The regulation of social meaning. The University of Chicago Law Review, vol. 62, n. 3, 1995, p. 943-1045. 
LOHMANN, Susanne. Information aggregation through costly political action. The American Economic Review, vol. 84, n. 3, 1994, p. 518-530.

LOURY, Glenn C. Self-censorship in public discourse. Rationality and Society, vol. 6, n. 4, 1994, p. 428-461. MAS-COLELL, Andreu et al. Microeconomic theory. Nova Iorque: Oxford University Press, 1995.

MCADAMS, Richard H.. Cooperation and conflict: the economics of group status production and race discrimination. Harard Law Review, vol. 108, n. 5, 1995, p. 1003-1084.

. The origin, development, and regulation of norms. Michigan Law Review, vol. 96, n. 2. 1997, p. 338-433. MILGROM, Paul; ROBERTS, John. Price and advertising signals of product quality. The Journal of Political Economy, vol. 94, n. 4, 1986, p. 796-821.

NASH, Nathaniel C. The new symbol of Germany: faith in a scrap of paper. 25 jun., 1995.

NETANYAHU, B. The origins of the inquisition in fifteenth century Spain 1052-1054. Nova Iorque: [s.n.], 1995. PESENDORFER, Wolfgand. Design innovation and fashion cycles. The American Economic Review, vol. 85, n. 4, 1995, p. 771-792.

PILDES, Richard H.. The unintended cultural consequences of public policy: a comment on the symposium. Michigan Law Review, vol. 89, n. 4, 1991, p. 936-978.

; NIEMI, Richard G. Expressive harms, "Bizarre districts", and voting rights: evaluating election-district appearances after Shaw v. Reno. Michigan Law Review, vol. 92, n. 3, 1993, p. 483-587.

POSNER, Eric A.. The regulation of groups: the influence of legal and nonlegal sanctions on colletive action. The University of Chicago Law Review, vol. 63, n. 1, 1996a, p. 133-197.

. The legal regulation of religious groups. Legal Theory, vol. 33. n. 2, 1996b.

. Law, economics and inefficient norms. University Pennsylvania Law Review, vol. 144, n. 5, 1996c, p. $1697-1744$.

Altruism, status, and trust in the law of gifts and gratuitous promises Wisconsin Law Review, 1997, p. 567-609.

Efficient norms. In: NEWMAN, Peter (Ed.). The new palgrave dictionary of economics and the law. Nova Iorque: Palgrave Macmillan, 1998.

PRESSER, Stanley; TRAUGOTT, Michael. Little white lies and social science models: correlated reponse errors in a panel study of voting. The Public Opinion Quarterly, vol. 56, n. 1, 1992, p. 77-86.

RADIN, Maragaret Jane. Market-inalienability. Harvard Law Review, vol. 100, n. 8, 1987, p. 1849-1937.

RASMUSEN, Eric. Lobbying When decisionmaker can acquire independent information. Public Choice, vol. 77, n. 4, 1993, p. 899-913.

The economist of desecration: flag burning and related activities. The Journal of Legal Studies, vol. 27, n. 2, 1998, p. 245-269.

REEVES, Thomas C. McCarthyism. 3. ed. Malabar: R.E. Krieger Pub. Co., 1989.

ROBACK, Jennifer. Racism as rent seeking. Economic Inquiry, vol. 27, n. 4, 1989, p. 661-681.

SACK, Kevin. Symbols of old south feed a new bitterness. The New York Times. 8 fev., 1997, at 1.

SCHELLING, Thomas C. The strategy of conflict. Cambridge: Harvard University Press, 1960.

SHENON, Philip. Battling over a national symbol: it's on the menu. The New York Times. 10 jul. 1995.

SUNSTEIN, Cass R.. Social roles and social norms.

Eric A. Posner

University of Chicago

1111, East 60th Street - IL 60637

Chicago, EUA

eposnerduchicago.edu 